\title{
Oblique reactivation of lithosphere-scale lineaments controls rift physiography - the upper-crustal expression of the Sorgenfrei-Tornquist Zone, offshore southern Norway
}

\author{
Thomas B. Phillips ${ }^{1}$, Christopher A.-L. Jackson ${ }^{1}$, Rebecca E. Bell ${ }^{1}$, and Oliver B. Duffy ${ }^{2}$ \\ ${ }^{1}$ Basins Research Group (BRG), Department of Earth Science and Engineering, Imperial College, \\ South Kensington Campus, Prince Consort Road, London, SW7 2BP, UK \\ ${ }^{2}$ Bureau of Economic Geology, Jackson School of Geosciences, The University of Texas at Austin, \\ University Station, Box X, Austin, TX 78713-8924, USA
}

Correspondence: Thomas B. Phillips (tbphil13@gmail.com)

Received: 30 August 2017 - Discussion started: 7 September 2017

Revised: 5 March 2018 - Accepted: 8 March 2018 - Published: 9 April 2018

\begin{abstract}
Pre-existing structures within sub-crustal lithosphere may localise stresses during subsequent tectonic events, resulting in complex fault systems at upper-crustal levels. As these sub-crustal structures are difficult to resolve at great depths, the evolution of kinematically and perhaps geometrically linked upper-crustal fault populations can offer insights into their deformation history, including when and how they reactivate and accommodate stresses during later tectonic events. In this study, we use borehole-constrained 2-D and 3-D seismic reflection data to investigate the structural development of the Farsund Basin, offshore southern Norway. We use throw-length (T-x) analysis and fault displacement backstripping techniques to determine the geometric and kinematic evolution of $\mathrm{N}-\mathrm{S}$ - and $\mathrm{E}-\mathrm{W}$-striking upper-crustal fault populations during the multiphase evolution of the Farsund Basin. N-S-striking faults were active during the Triassic, prior to a period of sinistral strike-slip activity along E-W-striking faults during the Early Jurassic, which represented a hitherto undocumented phase of activity in this area. These E-W-striking upper-crustal faults are later obliquely reactivated under a dextral stress regime during the Early Cretaceous, with new faults also propagating away from pre-existing ones, representing a switch to a predominantly dextral sense of motion. The E-W faults within the Farsund Basin are interpreted to extend through the crust to the Moho and link with the Sorgenfrei-Tornquist Zone, a lithosphere-scale lineament, identified within the sub-crustal lithosphere, that extends $>1000 \mathrm{~km}$ across central Europe. Based on this geometric linkage, we infer that the
\end{abstract}

E-W-striking faults represent the upper-crustal component of the Sorgenfrei-Tornquist Zone and that the SorgenfreiTornquist Zone represents a long-lived lithosphere-scale lineament that is periodically reactivated throughout its protracted geological history. The upper-crustal component of the lineament is reactivated in a range of tectonic styles, including both sinistral and dextral strike-slip motions, with the geometry and kinematics of these faults often inconsistent with what may otherwise be inferred from regional tectonics alone. Understanding these different styles of reactivation not only allows us to better understand the influence of sub-crustal lithospheric structure on rifting but also offers insights into the prevailing stress field during regional tectonic events.

\section{Introduction}

Pre-existing structures, such as prior fault populations, shear zones and terrane suture zones, are present throughout the lithosphere, where they may influence the geometry and evolution of upper-crustal rift systems forming during later tectonic events (e.g. Bellahsen et al., 2013; Bird et al., 2014; Bladon et al., 2015; Brune et al., 2017; Daly et al., 1989; Doré et al., 1997; Gontijo-Pascutti et al., 2010; Graversen, 2009; Mogensen, 1995; Morley et al., 2004; Phillips et al., 2016; Salomon et al., 2015; Whipp et al., 2014). The geometry and origin of pre-existing structures in the upper crust, such as pre-existing faults or shear zones, can often be di- 
rectly imaged, i.e. in the field or on seismic reflection data, thus allowing their role during subsequent rifting to be investigated (e.g. Bladon et al., 2015; Fazlikhani et al., 2017; Kirkpatrick et al., 2013; Phillips et al., 2016; Reeve et al., 2013). However, the geometry and physical properties of deeperlying structures in sub-crustal lithosphere are less well constrained, with information provided primarily by whole crust to lithosphere imaging geophysical methods such as seismic tomography, deep seismic reflection surveys, seismic refraction surveys and potential field imaging. Although able to image these structures to substantial, sub-crustal depths, such techniques are relatively low resolution, thereby limiting our ability to interpret the geological origin of such structures and thus hampering efforts to examine how they may influence the structural style and kinematics of later formed rift systems.

In previously rifted areas, structures within the sub-crustal lithosphere are often associated with complex upper-crustal rift systems, which may locally follow structural trends oblique to those predicted by extension of homogeneous lithosphere (Bergerat et al., 2007; Daly et al., 2014; Graversen, 2009; Holdsworth et al., 2001; Le Breton et al., 2013; Tommasi and Vauchez, 2001). Although exactly how these anomalous rift systems link to deeper structures is uncertain, their geometry and kinematic evolution can record the regional tectonic history, often throughout multiple stages of reactivation and under the influence of pre-existing structures at deeper levels (e.g. Bergerat et al., 2007; Brune et al., 2017; Corti, 2009; Mogensen, 1994). If we are able to establish a link between these sub-crustal structures and upper-crustal fault populations, we can use the evolution of the latter to examine the kinematic response of structures in the sub-crustal lithosphere during regional tectonic events. To accomplish this, we first need data that allow us to examine and link the structures at both deep and shallow levels. We can then use high-resolution datasets, focused at shallower levels, to extract detailed information which can be applied to the evolution of the whole system.

In this study, we use borehole-constrained 2-D and 3-D seismic reflection data to analyse the geometric and kinematic evolution of an upper-crustal fault population on the southern margin of the E-trending Farsund Basin, offshore southern Norway (Fig. 1a). The Farsund Basin is situated above the NW- to W-trending Sorgenfrei-Tornquist Zone (STZ), a major pan-central European lineament that is defined by a sharp change in lithospheric thickness at subcrustal depths (Babuška and Plomerová, 2004; Cotte and Pedersen, 2002; Hossein Shomali et al., 2006; Mazur et al., 2015; Wylegalla et al., 1999). The Farsund Basin is characterised by E-W- and N-S-striking upper-crustal fault sets that have been periodically active throughout the multiphase tectonic evolution of the North Sea. We first establish a geometric link between the seismically imaged upper-crustal faults defining the Farsund Basin, and the change in lithospheric thickness at depth, arguing that the former is geomet- rically linked to and represents the upper-crustal expression of the latter. Having established this geometric link, we then analyse the detailed geometric and kinematic evolution of the upper-crustal fault sets, using the observed deformation history to infer the kinematic response of the lithosphere-scale STZ to several regional tectonic events. We show that NS-striking faults were active during the Triassic, with some apparent activity occurring along segments of E-W faults at this time. The main period of activity along the main, E-W-striking faults occurred later, during the Early Cretaceous. Our quantitative fault analyses highlight a previously unrecognised period of sinistral strike-slip activity along EW-striking faults during the Early-Middle Jurassic. During the Late Jurassic - Early Cretaceous extension, the stress regime switches, with oblique dextral reactivation of the EW-striking faults.

The E-W-striking faults defining the Farsund Basin represent the upper-crustal component of the lithosphere-scale STZ. These faults, which are often non-optimally oriented with respect to the regional stress field, are reactivated in a range of styles during multiple tectonic events, representing activity along the whole lithosphere-scale STZ. We find that the sense of motion and style of reactivation along the STZ, as identified from the upper-crustal fault populations, reflects the prevailing regional stress field during these tectonic events.

\section{Geological setting}

This study examines an approximately $1000 \mathrm{~km}^{2}$ area offshore southern Norway, focusing on the western Farsund Basin (Fig. 1). The E-trending basin is bordered to the south by the Norwegian-Danish Basin and to the north by the Ntrending Eigerøy Horst, Varnes Graben and Agder Horst, from west to east, respectively (Fig. 1c). The basin extends westwards to the Stavanger Platform and merges with the Danish sector of the Norwegian-Danish Basin to the east (Christensen and Korstgård, 1994; Liboriussen et al., 1987; Fig. 1a). The basin overlies the inferred westernmost extent of the STZ (Pegrum, 1984; Fig. 1a). Here, we first establish the regional geological history of the area, before describing the STZ and placing it into this context.

\subsection{Regional geological history}

Rift basins within the study area and the wider North Sea have been active during multiple regional tectonic events since at least the Carboniferous-Permian (Deeks and Thomas, 1995; Erlström et al., 1997; Graversen, 2009; Jensen and Schmidt, 1993; Michelsen and Nielsen, 1993; Mogensen, 1995; Mogensen and Korstgård, 2003; Thybo, 2000). Variscan orogenesis drove regional N-S-directed shortening in the Carboniferous-Permian, resulting in the formation of a regional W- to NW-trending dextral strike- 


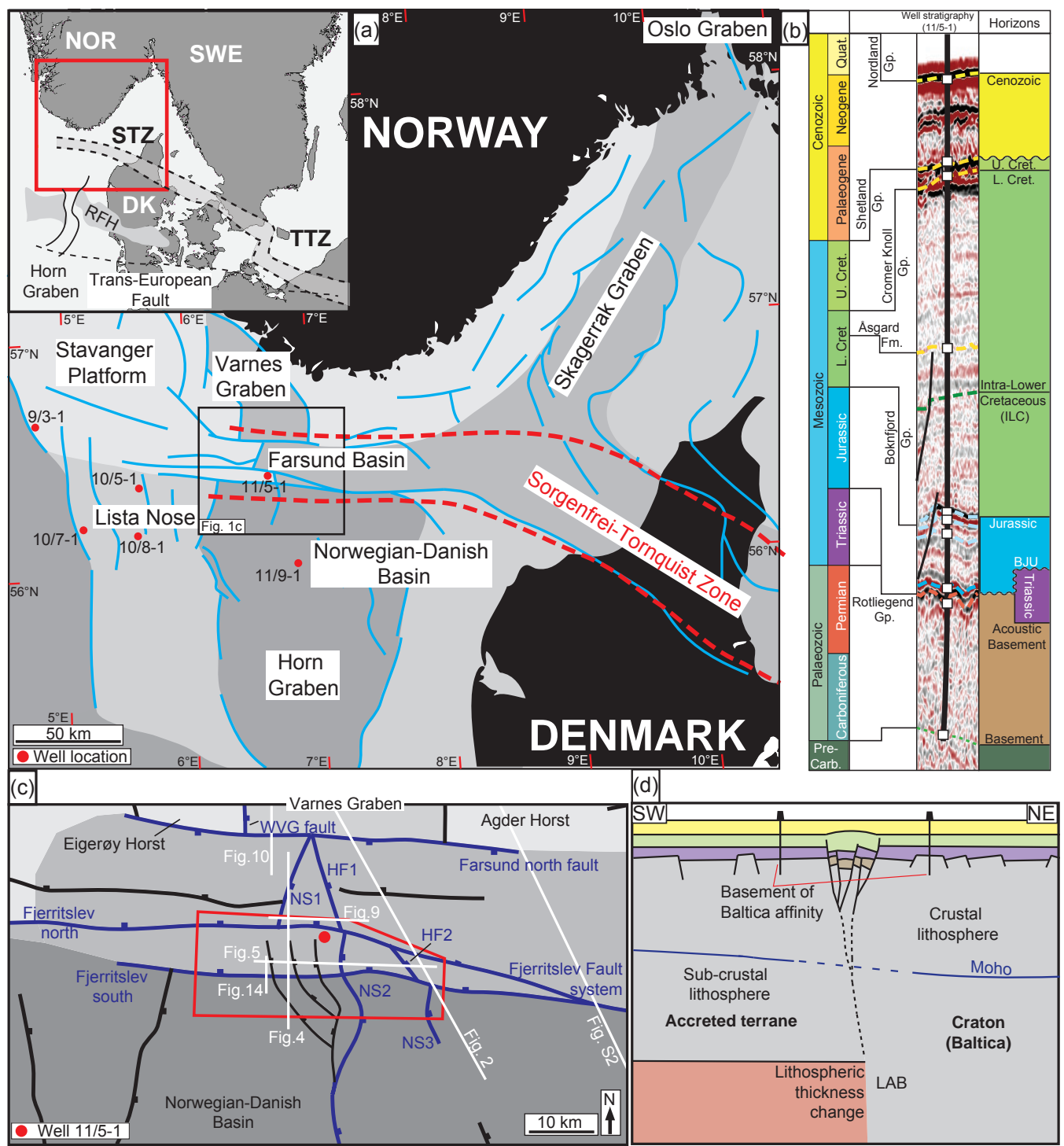

Figure 1. (a) Regional map of the study area showing the relation to the major structural elements and fault networks. Faults are based on interpretations made in this study with regional faults and the names of structural elements based on the Norwegian Petroleum Directorate (NPD) database. Well locations used to constrain ages of stratigraphic horizons are shown in red. Inset: regional map of the area showing the location and geometry of the Tornquist Zone. TTZ - Teisseyre-Tornquist Zone, STZ - Sorgenfrei-Tornquist Zone, RFH - Ringkøbing-Fyn High. (b) Stratigraphic column showing the stratigraphy encountered in well 11/5-1 (located within the 3-D volume) and the major tectonic events to have affected the region. (c) Map showing the fault networks present across the Farsund Basin (those referred to in the text shown in blue), the location of the 3-D seismic volume and the main figures used throughout the study. (d) Schematic cross-section, based on a NE-SW- to N-S-oriented section across the Sorgenfrei-Tornquist Zone, showing the Sorgenfrei-Tornquist Zone as defined at both upperand sub-crustal depths, and the potential relationship between the two.

slip system, incorporating the W-trending Fjerritslev faults (Skjerven et al., 1983), in addition to several N- to NEtrending structures such as the Varnes and Skagerrak grabens, situated north and east of the study area, respectively (Fig. 1a; Heeremans and Faleide, 2004; Heeremans et al., 2004; Lassen and Thybo, 2012; Ro et al., 1990).
Fault systems within the study area were intermittently active during the Mesozoic in response to several tectonic events affecting the broader North Sea (e.g. Bergerat et al., 2007; Deeks and Thomas, 1995; Erlström et al., 1997; Liboriussen et al., 1987; Mogensen, 1995; Mogensen and Jensen, 1994; Mogensen and Korstgård, 2003). During the PermianTriassic, E-W continental extension occurred in response to 
the breakup of Pangaea, leading to the formation of a predominately N-trending rift across the North Sea (e.g. Bell et al., 2014; Færseth, 1996; Ziegler, 1992). In the Horn Graben, south of the Farsund Basin, rifting and associated activity on N-S-striking faults were initiated during the Late Permian (Vejbæk, 1990; Fig. 1a). Rifting migrated northwards into the Norwegian-Danish Basin during the Triassic, towards the southern margin of the study area, where additional N-S-striking faults occur (Fig. 1c). An additional rift phase, centred on the central North Sea and related to the collapse of a Middle Jurassic thermal dome (Rattey and Hayward, 1993; Underhill and Partington, 1993), was initiated in the Late Jurassic, continuing until the Early Cretaceous. The extension direction during this rift phase varies spatially, with NW-SE to E-W extension proposed for areas north of the study area in the northern North Sea (e.g. Bell et al., 2014; Brun and Tron, 1993; Doré et al., 1997; Færseth, 1996) and NE-SW extension proposed south of the study area in the Central Graben and southern North Sea (Coward et al., 2003). During the Late Cretaceous, horizontal shortening, related to far-field tectonic effects from the Alpine Orogeny, drove basin inversion within several North Sea sedimentary basins (Biddle and Rudolph, 1988; Cartwright, 1989; Jackson et al., 2013; Mogensen and Jensen, 1994; Phillips et al., 2016). This inversion was amplified along the upper-crustal expression of the STZ (Thybo, 2000), being associated with regional uplift and the reverse reactivation of basin-bounding faults (e.g. Bergerat et al., 2007; Deeks and Thomas, 1995; Jensen and Schmidt, 1993; Liboriussen et al., 1987; Mogensen and Jensen, 1994). Further uplift and erosion occurred during the Neogene due to uplift of the South Swedish Dome (Japsen et al., 2002; Jensen and Schmidt, 1993), resulting in erosion of Cretaceous strata across much of the study area.

The E-trending Farsund Basin is oriented at an unusually high angle, in many cases almost perpendicular, to largely $\mathrm{N}$ trending structures across the North Sea. To the south, in the Horn Graben, faults primarily strike N-S to NW-SE (Glennie, 1997; Vejbæk, 1990), whereas to the north and west, where they define the Varnes Graben and Lista Nose, they strike N-S (Heeremans et al., 2004; Lewis et al., 2013; Skjerven et al., 1983; Fig. 1a). Furthermore, to the east, NE-SWand NW-SE-striking faults occur in the Skagerrak Graben and along the eastern part of the STZ, respectively (Mogensen and Jensen, 1994; Ro et al., 1990; Fig. 1a). The E-W geometry of the faults defining the Farsund Basin means that they are not optimal for reactivation during any of the North Sea regional tectonic events outlined above, suggesting they record a hitherto undocumented phase of tectonic activity or, more likely, are influenced by a pre-existing structure such as the STZ.

\subsection{Geometry and origin of the Sorgenfrei-Tornquist Zone}

The Tornquist Zone forms a lineament that spans the lithosphere and extends $>1000 \mathrm{~km}$ across central and northern Europe (Alasonati Tašárová et al., 2016; Berthelsen, 1998; Mazur et al., 2015; Pegrum, 1984). The Tornquist Zone comprises two segments: the Teisseyre-Tornquist Zone (TTZ) in the south, extending northwest from the Carpathian orogenic front to the Rønne Graben (e.g. Alasonati Tašárová et al., 2016; Berthelsen, 1998; Grad et al., 1999; Guterch et al., 1986; Pharaoh, 1999; Fig. 1a) and the Sorgenfrei-Tornquist Zone (STZ) in the north, continuing northwest from the Rønne Graben to the Farsund Basin (e.g. Babuška and Plomerová, 2004; Berthelsen, 1998; Pegrum, 1984; Thybo, 2000) and possibly extending further westwards beneath the main North Sea rift (Pegrum, 1984; Fig. 1a).

The Tornquist Zone, including the STZ and TTZ, has been extensively studied using a variety of geological and geophysical methods, including seismic tomography (Cotte and Pedersen, 2002; Voss et al., 2006), seismic refraction (Alasonati Tašárová et al., 2016; Guterch and Grad, 2006; Guterch et al., 1986), seismic anisotropy (Babuška and Plomerová, 2004) and seismic reflection surveying (Grad et al., 1999; Lassen and Thybo, 2012; Thybo, 2000). These data suggest that the lineament separates thick, old cratonic lithosphere of the East European Craton, including Baltica, from the younger, thinner lithosphere associated with assorted Palaeozoic terranes that comprise present-day central and western Europe; the lineament thus represents a major change in lithospheric properties and thickness (e.g. Babuška and Plomerová, 2004; Berthelsen, 1998; Cotte and Pedersen, 2002; Erlström et al., 1997; Kinck et al., 1993; Michelsen and Nielsen, 1993; Pegrum, 1984; Pharaoh, 1999; Voss et al., 2006).

At the junction of the TTZ and STZ, offshore southern Sweden, a zone of NW-diverging splay faults, termed the "Tornquist Fan" occur, demarcated to the north and south by the STZ and a further regional structure, the Trans-European Fault, respectively (Thybo, 2000, 2001). Here, the STZ is still defined as a change in lithospheric thickness at subcrustal, i.e. upper mantle, levels (e.g. Babuška and Plomerová, 2004; Berthelsen, 1998; Cotte and Pedersen, 2002). Geological evidence, in the form of drilled crystalline basement, shows that basement of Baltica affinity is present on either side of the STZ (Berthelsen, 1998), indicating that the margin of Baltica as identified at sub-crustal depths does not correspond to the same location at upper-crustal levels, with crystalline basement of Baltica affinity continuing south of the STZ (Fig. 1d). At upper-crustal levels, the STZ is defined by a zone of Late Cretaceous inversion (e.g. Bergerat et al., 2007; Deeks and Thomas, 1995; Michelsen and Nielsen, 1993; Mogensen, 1995; Mogensen and Jensen, 1994; Pegrum, 1984), which correlates in plan view to the STZ as defined by the change in lithospheric thickness at sub-crustal 
levels (Babuška and Plomerová, 2004; Liboriussen et al., 1987; Mogensen and Jensen, 1994). Several authors suggest the STZ represents a weak zone during later tectonic events, acting to accommodate stresses between adjacent crustal blocks (Mogensen and Jensen, 1994; Mogensen and Korstgård, 2003); however, the link between different structural levels and, therefore, how a change in lithospheric thickness may behave kinematically and influence the development of overlying upper-crustal rift systems' later events, has not been established. Understanding how these sub-crustal structures are expressed within rift systems is vital to understanding both the local rift evolution and the causal stress field.

\section{Data and methods}

\subsection{Data}

Seismic interpretation focused on a $500 \mathrm{~km}^{2}$, boreholeconstrained 3-D seismic reflection dataset covering the southern margin of the Farsund Basin (Fig. 1c). These data image to $4 \mathrm{~s}$ two-way time (TWT; $\sim 6 \mathrm{~km}$ ), having inline and crossline spacings of 18.75 and $12.5 \mathrm{~m}$, respectively. Regional 2-D seismic reflection datasets covering the entire basin were used to provide regional structural context for the area imaged by the 3-D dataset; this 2-D dataset consists of closely spaced $(\sim 3 \mathrm{~km}), \mathrm{N}$-trending seismic sections that are oriented perpendicular to the dominant E-W structural trend (see Fig. 1c for the locations of sections used in this study and Table S1 in the Supplement for additional information on acquisition and processing parameters). The 2-D seismic reflection data are zero phase and follow the SEG reverse polarity convention whereby a downward increase in acoustic impedance is represented by a trough (red) and a downward decrease in acoustic impedance is represented by a peak (black). The 3-D seismic volume follows the opposite (normal) convention. Image quality is excellent throughout the 2-D and 3-D datasets at shallow levels, although quality deteriorates at depth; the 2-D sections image to deeper structural levels (7 s TWT), with some reaching $12 \mathrm{~s}$ TWT (e.g. Fig. 2), and cover a wider area (approximately $2000 \mathrm{~km}^{2}$ ) than the 3-D dataset. The ages of key horizons are constrained using stratigraphic information from well 11/5-1, located in the area covered by the 3-D dataset, and wells 9/3-1, 10/5-1, $10 / 7-1,10 / 8-1$ and 11/9-1, located in the wider region imaged by the 2-D seismic data (Fig. 1a). Checkshot information from these wells was used to convert structural measurements (i.e. specific spot measurements of fault cut-off depths and horizon depths for fault offset and thickness calculations) from the time to the depth domain.

\subsection{Seismic interpretation and isochron generation}

We mapped six key tectonostratigraphic horizons throughout the area, along with two supplementary ones (Figs. 1b, 3).
The six main horizons define the main stratigraphic intervals of the basin and correspond to the acoustic basement surface, the base Jurassic unconformity (BJU), the top Jurassic surface, the top Lower Cretaceous, base Cenozoic unconformity and the seabed (Figs. 1b, 2). Where present, the base of the Upper Permian Zechstein Supergroup salt represents the acoustic basement, i.e. the deepest mappable coherent reflection within the study area (Figs. 3, 4). Where Zechstein salt is absent and Triassic strata directly overlie pre-Upper Permian strata, or where erosion by the BJU removes Triassic strata completely, we map these basal reflections (i.e. base Triassic or BJU) as the acoustic basement (Figs. 4, 5). Due to the large thickness of the Lower Cretaceous interval and the associated burial of the tips of the main E-W-striking faults, we mapped an internal surface within the Lower Cretaceous interval, termed the intra-Lower Cretaceous (ILC) horizon (Figs. 4, 5). A further horizon, proposed as corresponding to the base of a Carboniferous-Permian aged interval was mapped locally beneath the acoustic basement horizon. Within the 3-D volume, we generated a series of isochrons (TWT interval thickness maps) between horizons to define the structural style and infer the subsidence history of the basin (Fig. 6). These isochrons correspond to the Triassic interval (between the acoustic basement and base Jurassic unconformity), the Jurassic (between the BJU and top Jurassic) and the Lower Cretaceous (between the top Jurassic and top Lower Cretaceous).

Within these surfaces, faults are represented by black polygons, defined by hangingwall and footwall cut-offs of the horizons against the fault plane (Figs. 3, 6). These cut-offs are used as input for quantitative fault analyses. The width of the polygon (i.e. the horizontal distance between the hangingwall and footwall cut-off) is representative of the fault heave. Due to difficulties in accurately determining the cutoffs and the fact that throw is much larger than heave in extensional settings (reducing potential measurement errors), we measured fault throw rather than heave in our quantitative fault analysis.

\subsection{Quantitative fault analysis}

To constrain the geometry and growth of the upper-crustal fault population, we mapped and performed quantitative analysis of the major faults delineating the basin. Horizon cut-offs, fault tip-lines and fault intersections (as defined by branch lines) were mapped to minimise artefacts that may lead to an incorrect assessment of fault kinematics (e.g. Duffy et al., 2015; Walsh et al., 2003; Yielding, 2016). Throw-length (T-x) plots, where throw is measured at regular intervals along the fault for different stratigraphic levels (see Appendix A), were then calculated and were subsequently used as input for fault displacement backstripping (Figs. 7, 8), a technique used to unravel the kinematic and geometric evolution of a fault throughout its history (see Appendix B; see Jackson et al., 2017). These analyses only record the ver- 


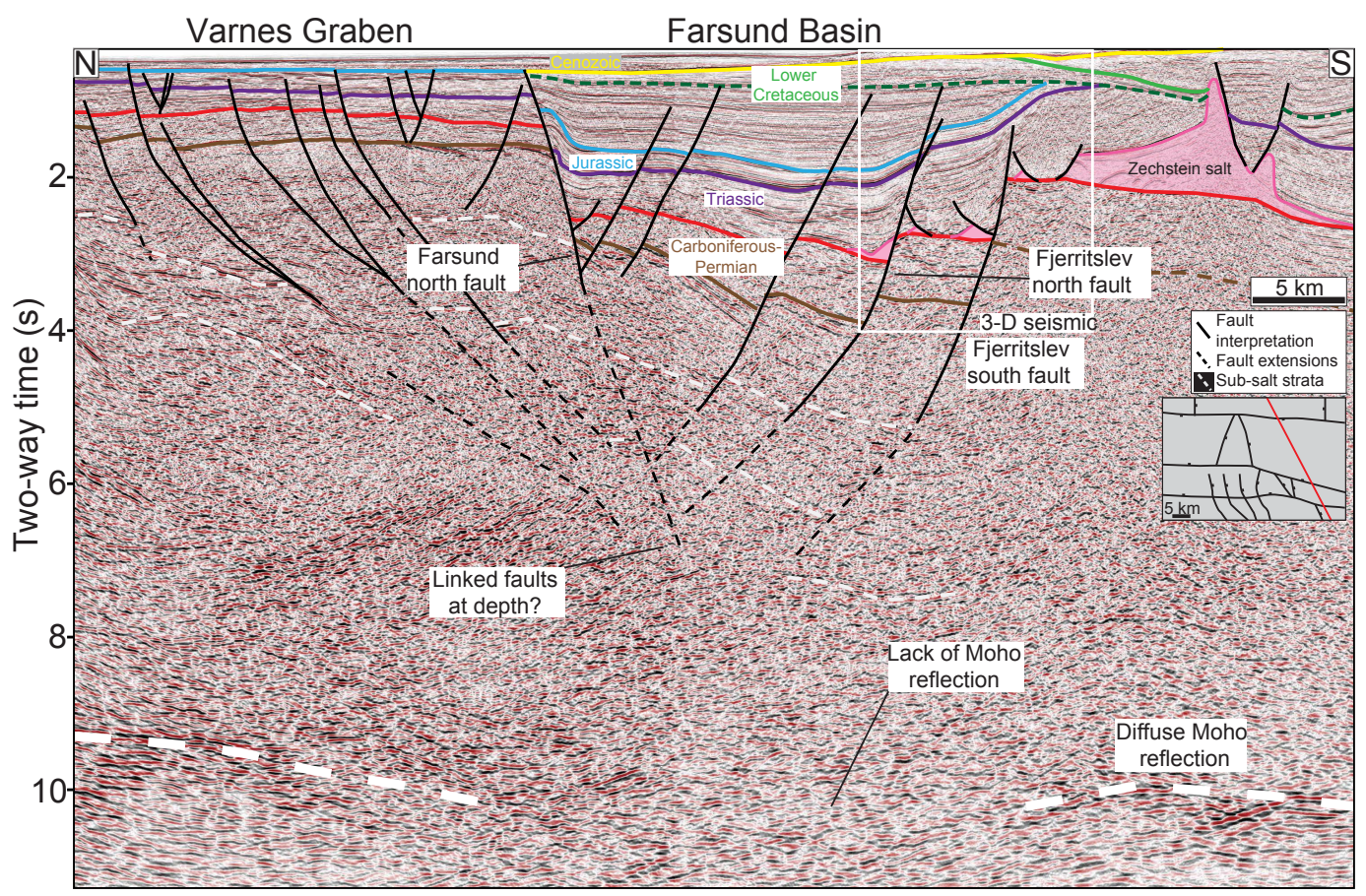

Figure 2. Interpreted N-S-oriented 2-D seismic section across the Farsund Basin showing the linked and crustal-scale nature of the E-Woriented basin bounding faults. The lack of Moho reflection directly beneath the basin may imply that the fault cross-cut the Moho in this area and extends through the crust. See Fig. 1c for location.

tical displacement along the fault plane throughout its evolution; we make no inferences as to how this throw accumulated (i.e. oblique slip/dip slip). T-x plots allow us to examine the distribution of throw along a fault and help elucidate its kinematic history. Fault displacement backstripping expands upon this; by systematically removing throw accrued during specific stratigraphic intervals, starting with the youngest, we are able to quantitatively examine the throw distribution along the fault throughout its history and hence determine its geometric evolution.

\section{Structural style of the Farsund Basin}

In Sect. 4.1, we document the crustal-scale geometry of the Farsund Basin and attempt to, at least geometrically, link faults defining the basin in the upper crust to the sub-crustal lithospheric "step" defined as the STZ. With this link established, in Sect. 4.2, we use seismic sections and TWT structure maps to outline and describe the detailed geometry of these upper-crustal fault systems across the southern margin of the basin, establishing a structural framework for use in later sections.

\subsection{Crustal-scale faulting}

The E-W-striking Fjerritslev north and Fjerritslev south faults delineate the southern margin of the Farsund Basin; these faults merge laterally to the east to form a single structure, the Fjerritslev Fault system (Fig. 1c). A S-dipping fault, termed the Farsund north fault, bounds the Farsund Basin to the north (Fig. 2), separating it from N-S-striking faults associated with the Varnes Graben (Fig. 1c). Projecting these basin-bounding faults downwards, based on their overall dip and subtle reflection terminations at depth, the N-dipping Fjerritslev north and south faults appear to merge with Sdipping faults on the northern margin of the basin, including the Farsund north fault, potentially at a depth of approximately $7 \mathrm{~s}$ TWT ( $15 \mathrm{~km}$; Fig. 2). Together, these structures thus appear to form a system that, at least superficially, resembles a negative flower structure (Fig. 2). Although the exact location and nature of this apparent geometric link at depth is uncertain due to poor seismic image quality, we infer that the faults defining the basin are geometrically linked, both along strike and down dip (Fig. 2). In plan view, the Fjerritslev north and south faults also merge eastwards (Fig. 1c).

We observe high-amplitude reflections 9-10 s TWT at the basin margins; we interpret these as Moho-related reflections, which are noticeably absent directly beneath the Farsund Basin (Fig. 2). In addition, east of the Farsund Basin, Moho-related reflectivity is observed at $10-12 \mathrm{~s}$ TWT (approximately $30 \mathrm{~km}$ ); a key observation in this location is that this reflectivity is offset by $1-2 \mathrm{~s}$ TWT $(4-5 \mathrm{~km})$ across the Fjerritslev Fault system (Kind et al., 1997; Lie and Huse- 


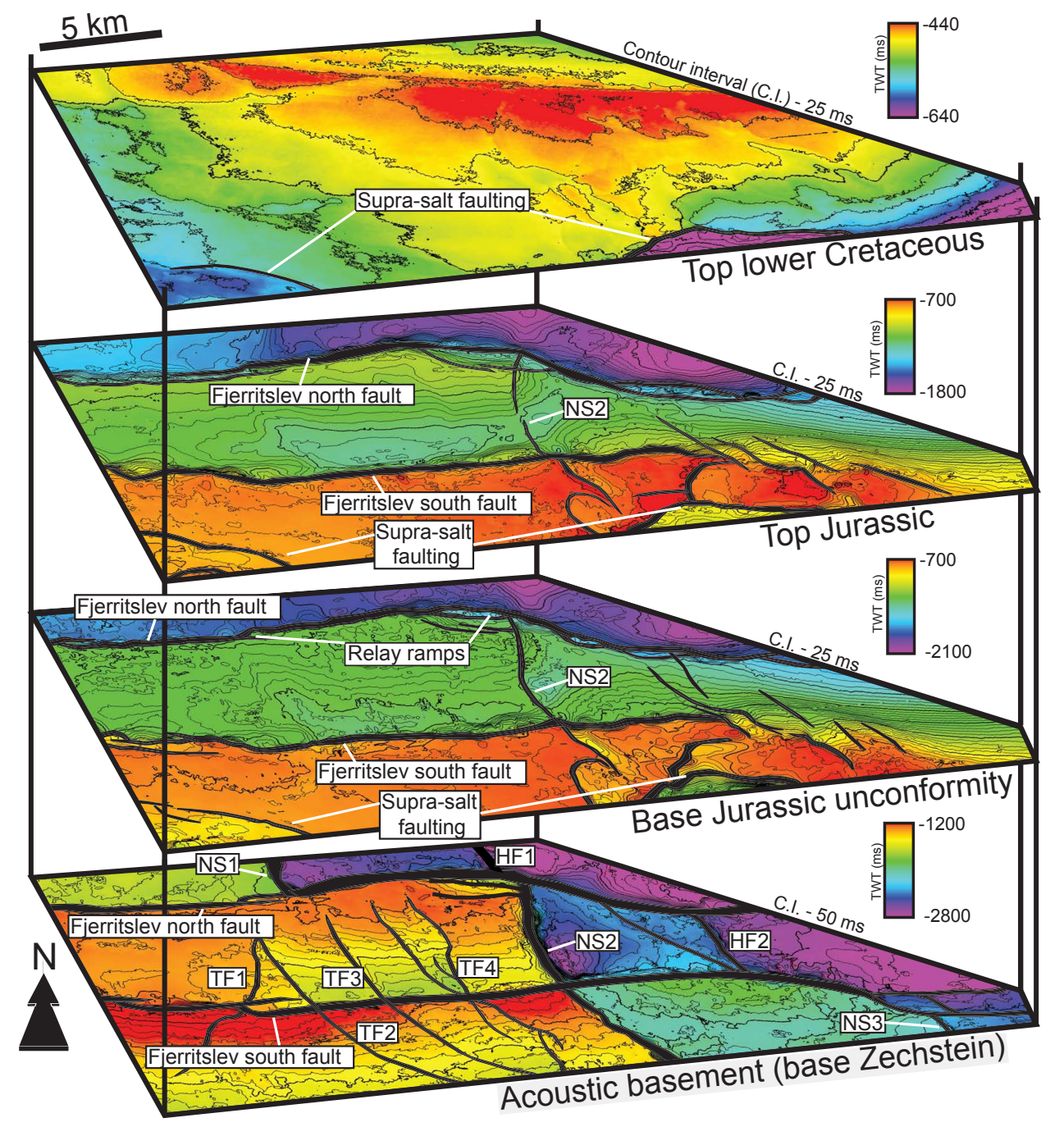

Figure 3. Two-way time structure maps of the key stratigraphic horizons used within this study, as mapped within the 3-D seismic volume. The acoustic basement (base Upper Permian Zechstein salt), base Jurassic unconformity, top Jurassic, and top Lower Cretaceous surfaces are shown. Vertical separation not to scale. See Fig. 1c for location of the 3-D seismic volume.

bye, 1994). Furthermore, again east of the Farsund Basin along the STZ, Deeks and Thomas (1995) observe a zone of high reflectivity within the lower crust beneath the STZ, which they interpret as an area where deformation is transferred between the upper- and sub-crustal lithosphere in a more ductile manner. We propose that the faults defining the Farsund Basin represent the brittle upper-crustal component of the STZ, although the exact nature of the linkage between the upper-crustal faults and sub-crustal lithospheric step is uncertain. One potential mechanism is that the crustal-scale faults offset the Moho, causing it to be poorly imaged below the basin. We speculate that these crustal-scale faults extend deeper below the Moho to link to the lithospheric step associated with the STZ as defined at sub-crustal levels (Figs. 1c, 2; e.g. Babuška and Plomerová, 2004; Berthelsen, 1998; Cotte and Pedersen, 2002). Based on the anomalous, overall E-W strike of the basin-bounding faults compared to the broader northerly trending North Sea rift (Fig. 1a) and the proposed linkage between the upper crust and sub-crustal lithosphere, we argue that, by studying the geometric and kinematic evolution of the well-imaged upper-crustal fault systems, we can gain a better understanding of the kinematic behaviour of the whole lithosphere-scale STZ.

\subsection{Upper-crustal fault geometries}

In plan view, across the southern margin of the Farsund Basin, the acoustic basement surface is characterised by the E-W-striking Fjerritslev north and south faults and a Ntrending fault population (Figs. 3, 4). The Fjerritslev north fault is approximately $70 \mathrm{~km}$ long (32 $\mathrm{km}$ within the 3-D vol- 

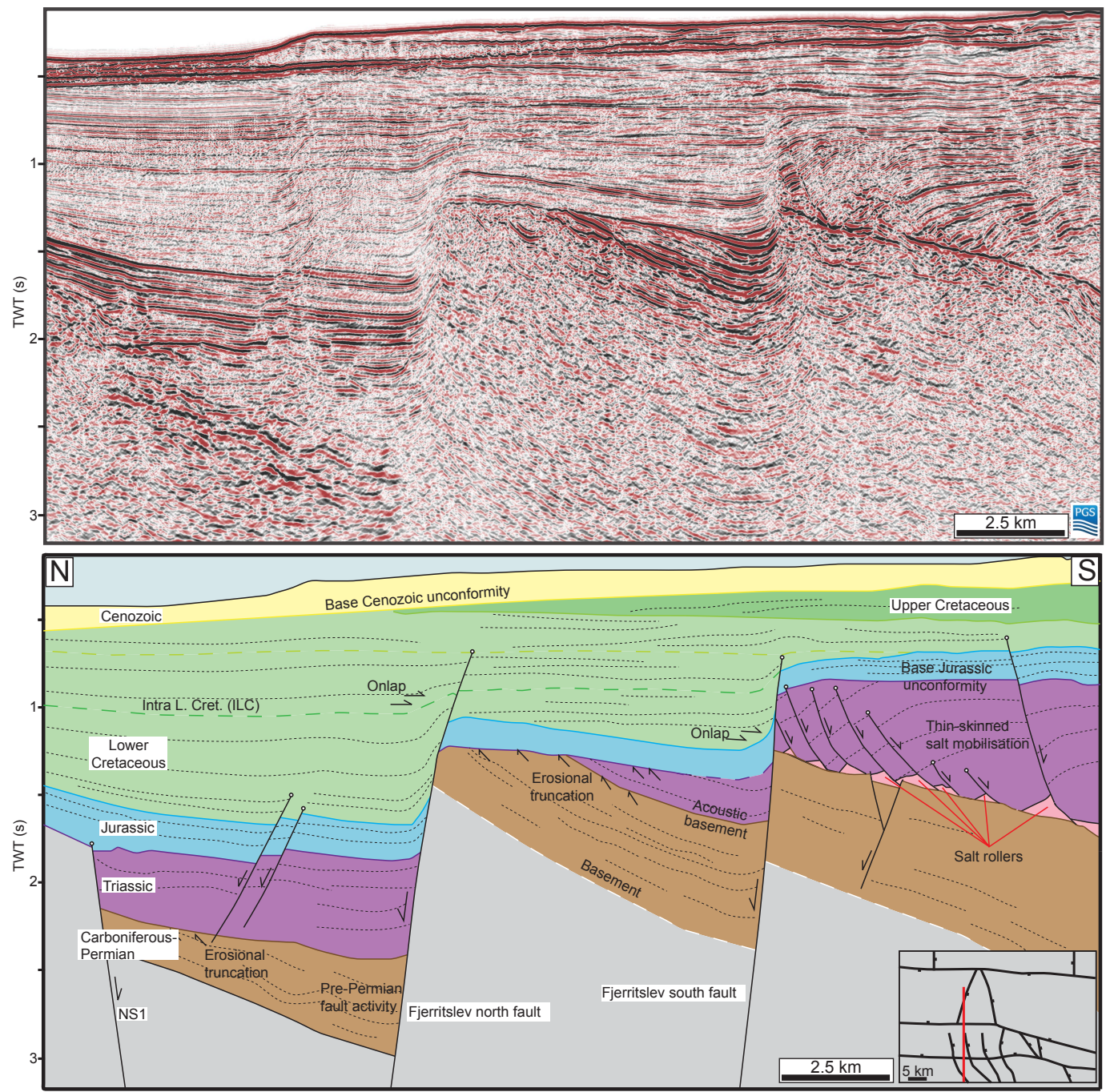

Figure 4. Uninterpreted and interpreted N-S-oriented 2-D seismic section across the Farsund Basin. The Fjerritslev south fault appears to show solely Early Cretaceous activity, with some apparent Triassic activity preceding Early Cretaceous activity along the Fjerritslev north fault. No pre-Permian activity is apparent across either fault. See Fig. 1c for location.

ume; Figs. 1a, 3), with a series of relay ramps separating the fault into three $10 \mathrm{~km}$ long segments within the area covered by the 3-D volume (Fig. 3). The Fjerritslev south fault is approximately $75 \mathrm{~km}$ long ( $38 \mathrm{~km}$ within the 3-D volume; Fig. 1a) and shares several branch lines with $\mathrm{N}-\mathrm{S}$-striking faults (Fig. 3).

Two major E-dipping, N-S-striking faults, hereby termed NS1 and NS2 from north to south, respectively, dissect the basin (Figs. 3, 5). NS1 and NS2 lie in the hangingwall and footwall of the Fjerritslev north fault, respectively, and also abut this structure. The two branch lines are laterally offset by approximately $10 \mathrm{~km}$. Further south, NS2 cross-cuts the Fjerritslev south fault (Fig. 3). We observe additional Nstriking, E-dipping faults within the hangingwalls of NS1 (i.e. HF1) and NS2 (i.e. HF2; Fig. 5). HF2 links and terminates against the Fjerritslev north and south faults (Fig. 3).
Another N-S-striking fault, termed NS3, is located east of HF2 where it abuts the footwall of the Fjerritslev south fault (Fig. 3). A series of minor ( $\sim 50 \mathrm{~ms}$ TWT throw), N-Sstriking faults is present across the footwall of NS2; these faults cross-cut the Fjerritslev south fault and are eroded by the BJU to the north, terminating at the acoustic basement surface within the footwall of the Fjerritslev north fault (TF14; Figs. 3, 5). Although not observed directly, based on 2-D seismic data located to the south of the 3-D dataset, we propose that these $\mathrm{N}-\mathrm{S}$-striking faults may merge, forming a single structure (Fig. 1c).

Supra-salt structural levels (i.e. BJU and above) are dominated by the E-W Fjerritslev north and south faults (Fig. 4), with a key observation being that $\mathrm{N}-\mathrm{S}$-striking faults, with the exception of NS2, are absent (Figs. 3, 5). At these structural levels, the Fjerritslev south fault terminates at the NW- 


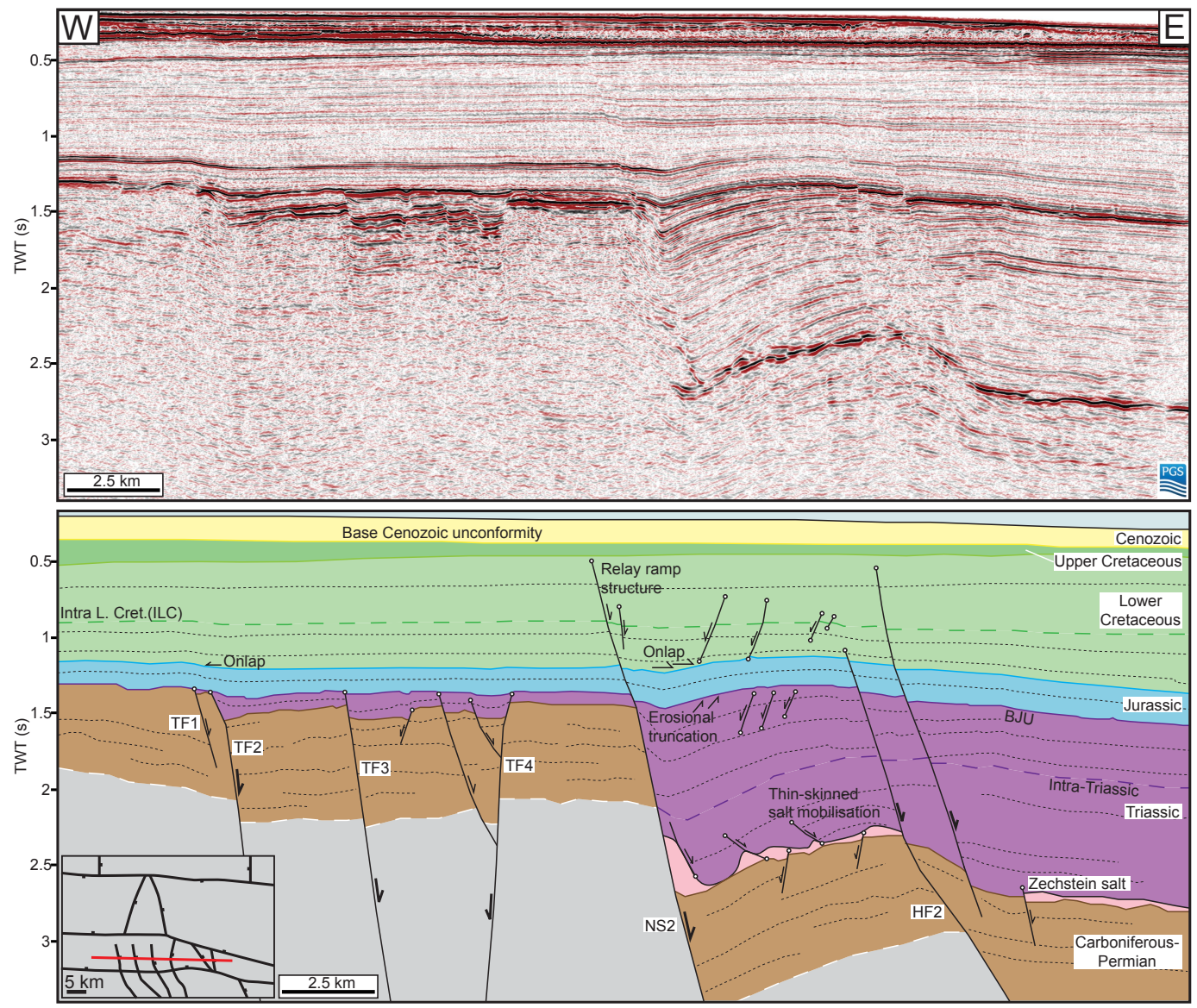

Figure 5. Uninterpreted and interpreted E-W-oriented seismic section (taken from 3-D volume) across the Farsund Basin. Triassic thickness changes are observed across N-S-striking faults, with other stratigraphic intervals appearing largely isopachous. See Fig. 1c for location.

SE-striking HF2 (Fig. 3). Numerous faults, displaying a range of strikes, are present within the footwall of the Fjerritslev south fault at supra-salt structural levels; these represent thin-skinned, salt-detached faults that are accordingly not expressed at sub-salt structural levels (i.e. the acoustic basement; Figs. 2, 4). No thick-skinned (i.e. basement-involved) faults are present at the top of the Lower Cretaceous; the only faults present are arcuate, broadly E-W-oriented, S-dipping, salt-detached faults located along the footwall of the Fjerritslev south fault (Figs. 3, 4).

\section{Tectonostratigraphic evolution of the Farsund Basin}

Having established the present structural style of the Farsund Basin, we here integrate observations from $\mathrm{N}$ - and E-trending seismic cross-sections (Figs. 4, 5) and sediment isochrons (Figs. 3,6) to broadly constrain the spatiotemporal patterns of faulting during basin development.

\subsection{Pre-upper Permian}

Regional 2-D seismic reflection data indicate the acoustic basement is reflective but contains very little in the way of coherent, mappable reflectivity. Discrete reflections likely represent Carboniferous-Permian strata (Figs. 4, 5; e.g. Mogensen and Jensen, 1994; Sørensen and Tangen, 1995). Acoustic basement reflections are truncated at base salt (or its laterally equivalent stratigraphic horizon where salt is absent; Fig. 4). Carboniferous-Permian strata are tabular in both the hangingwalls and footwalls of the Fjerritslev north and south faults, indicating these structures were inactive. Apparent thickening of Late Palaeozoic strata into the hangingwall of the Fjerritslev north fault appears to simply reflect increased updip erosion of strata below the BJU (Fig. 4). Synkinematic strata also appear absent in the hangingwall of NS2, although this may be due to poor at-depth imaging within the 3 -D volume (Fig. 5). Instead, Carboniferous-Permian strata appear to thicken regionally to the south (Figs. 2, 4). The seismic-stratigraphic architecture of sub-salt strata suggests E-W-striking faults were inactive during the CarboniferousPermian (Figs. 4, 5). 

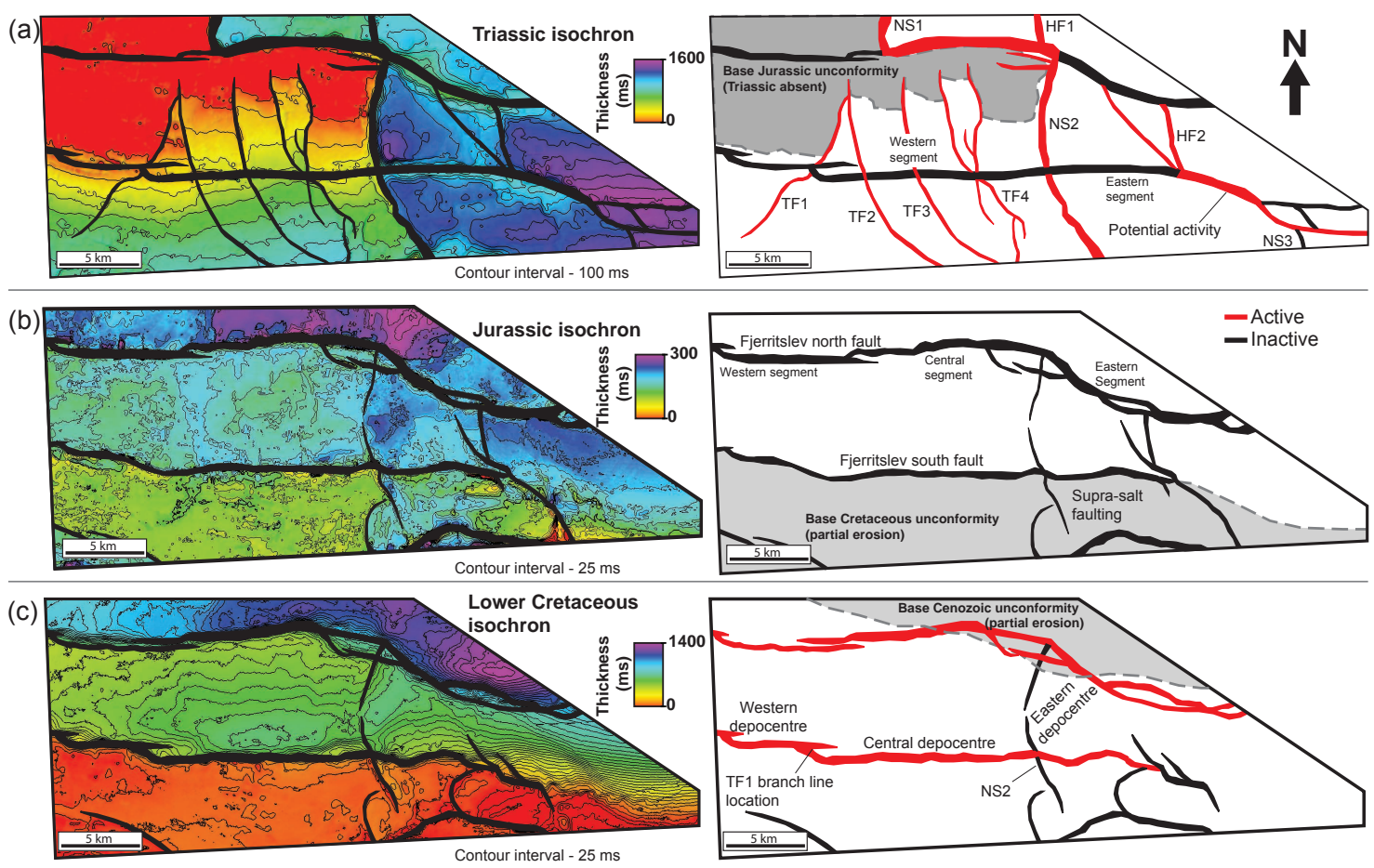

Figure 6. (a) Isochron showing thickness of the Triassic interval and the associated faults active during this interval based on sediment thickness changes and depocentres. (b) Isochron of Jurassic strata showing thickness and the faults that appear to have been active during this interval. (c) Isochron of Lower Cretaceous strata showing the faults that appeared to be active during this interval.

\subsection{Triassic}

The Triassic interval does not thicken into the Fjerritslev south fault along most of its length (Figs. 2, 4), although a depocentre, which may be related to salt withdrawal and not fault movement, may potentially be present within the hangingwall of the eastern segment (Fig. 6a). The Triassic interval also does not thicken towards the eastern part of Fjerritslev north fault (i.e. east of its branch line with NS2), suggesting at least this part of the fault was inactive at this time (Fig. 6a). A critical observation we make is that a thick, tabular, seemingly pre-kinematic package of Triassic strata is preserved within the hangingwall of the central segment of the E-W-striking Fjerritslev north fault (i.e. between its branch lines with NS1 and NS2; Figs. 4, 6a). With regards to activity along the $\mathrm{N}-\mathrm{S}$-striking faults, the Triassic interval thickens across NS1 and NS2 (Fig. 5, 6), with Triassic strata also preferentially preserved in the hangingwalls of other N-S faults beneath the BJU (Fig. 6a). Triassic strata are largely eroded across the footwall of NS2 and are completely eroded from the footwall of NS1, with the thickness of missing section increasing northwards (Fig. 4, 6a). Our observation that Triassic thickness changes principally reflect differential preservation of strata beneath the BJU indicates that any activity along depocentre-bounding faults must have occurred prior to BJU erosion in the Early Jurassic (Figs. 5, 6a). Therefore, Triassic activity predominately occurred on N-S-striking faults, with the central segment of the E-W Fjerritslev north fault and potentially the eastern segment of the Fjerritslev south fault also appearing active (Fig. 6a). The other segments of the E-W-striking Fjerritslev north and south faults were inactive at this time (Figs. 2, 4, $6 a)$.

\subsection{Jurassic}

The Jurassic interval is relatively thin across the basin (approximately $200 \mathrm{~ms}$ TWT, $\sim 250 \mathrm{~m}$ ) and of constant thickness within individual fault blocks (Figs. 2, 6b). A subtle, stepwise basinward thickening (approximately $60 \mathrm{~ms}$ TWT, $75 \mathrm{~m}$ ) occurs northwards across the Fjerritslev north and south faults (Fig. 6b), with relatively minor thickness changes (approximately $40 \mathrm{~ms}$ TWT, $50 \mathrm{~m}$ ) also occurring across NS1 and NS2 (Figs. 4, 6b). Based on the lack of obviously fault-driven, short-wavelength changes in Jurassic sediment thickness, we propose the Middle and Late Jurassic (i.e. post BJU-erosion) were a time of relative tectonic quiescence (Figs. 4, 6b).

\subsection{Cretaceous}

The Lower Cretaceous interval thickens northwards across the E-W-striking Fjerritslev south and north faults, reaching a maximum thickness of approximately $1400 \mathrm{~ms}$ TWT 


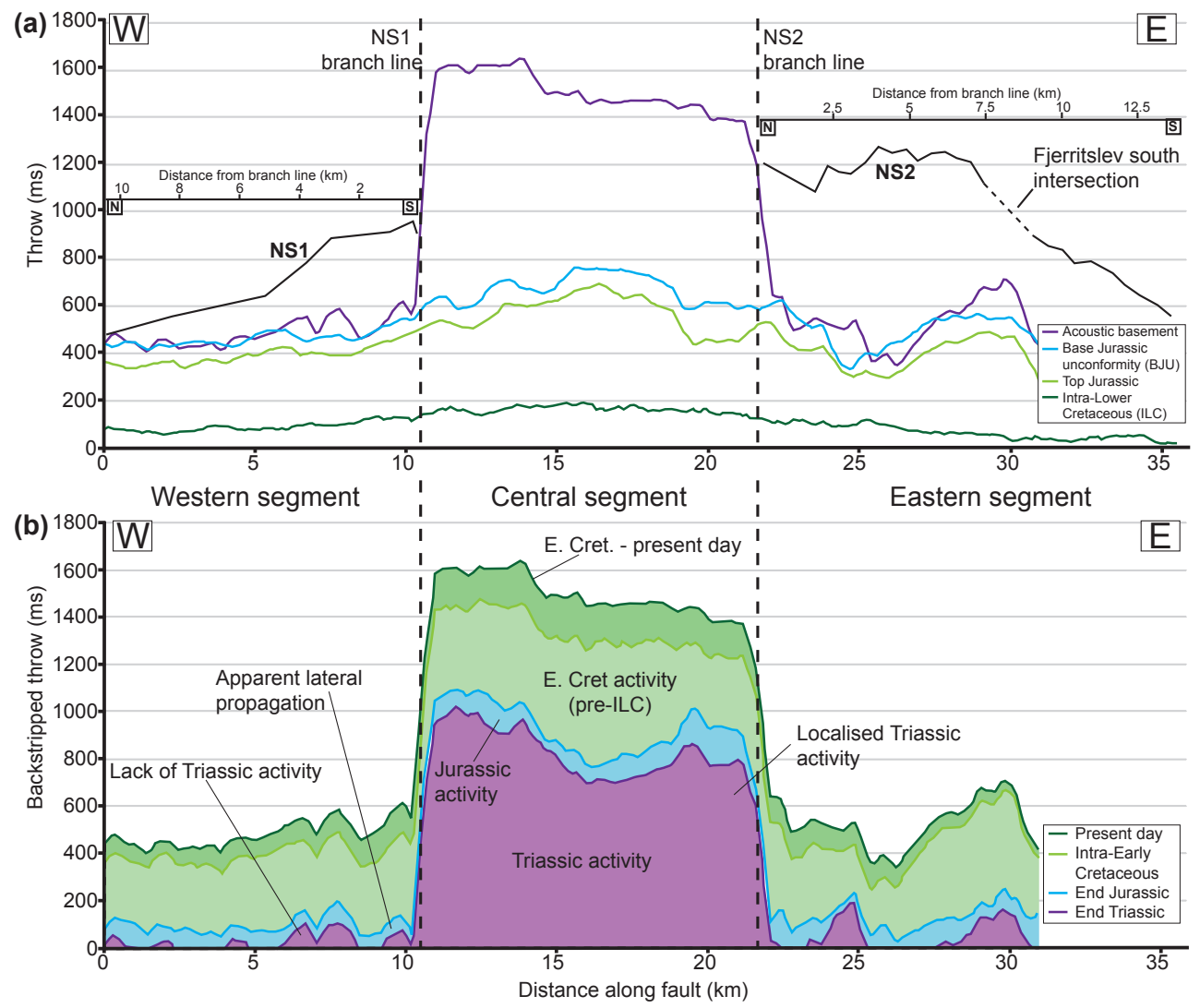

Figure 7. (a) Throw-length profiles calculated for major stratigraphic horizons along the Fjerritslev north fault showing the branch lines with other faults. Shown in black are the throw-length profiles for the NS1 and NS2 faults calculated across the acoustic basement horizon. Note the correspondence between the NS1 and NS2 fault branch lines and the marked increase in throw along the acoustic basement horizon. (b) Backstripped fault profile for the Fjerritslev north fault showing the kinematic evolution of the fault. The central segment accommodated throw during the Triassic, before the rest of the fault became active and throw accumulated along the length of the fault during the Early Cretaceous.

$(1800 \mathrm{~m})$ in the centre of the basin (Figs. 4, 6c). Fault-related thickening is observed along the entire length of the Fjerritslev north fault, with strata thickening eastwards towards the largest depocentre occurring next to the eastern segment (Fig. 6c). Three depocentres occur along the Fjerritslev south fault: a minor, E-trending depocentre in the west (approximately $700 \mathrm{~ms}$ TWT, $850 \mathrm{~m}$ ); a major E-trending depocentre situated between the TF1 branch line location and the NS2 branch line (approximately $850 \mathrm{~ms}$ TWT, $\sim 1000 \mathrm{~m}$; Fig. 6c); and a further, NE-trending depocentre to the east of the NS2 branch line (approximately $800 \mathrm{~ms}$ TWT, $\sim 900 \mathrm{~m}$; Fig. 6c). Lower Cretaceous strata do not appreciably thicken across $\mathrm{N}-\mathrm{S}$ faults, and this interval is partially eroded to the northwest by the base Cenozoic unconformity (Figs. 4, 6c). Upper Cretaceous strata are largely absent across the basin due to erosion along the base Cenozoic unconformity; strata of this age are only preserved along the southern basin margin (Figs. 2, 4).

\subsection{Summary of basin evolution}

Palaeozoic-Mesozoic deformation in the Farsund Basin was accommodated by both $\mathrm{E}-\mathrm{W}$ - and N-S-striking faults, although fault activity was strongly partitioned in time and space. Triassic faulting primarily occurred along N-Sstriking faults (Figs. 5, 6a), along with isolated segments of E-W-striking faults (Figs. 4, 6a). In contrast, in the Early Cretaceous, following Early-Middle Jurassic regional uplift and erosion and a period of relative tectonic quiescence during the Middle and Late Jurassic, activity preferentially occurred on E-W-striking Fjerritslev faults (Figs. 2, 4, 6c).

\section{Geometric and kinematic evolution of upper-crustal faults}

Having constrained, to the first order, the tectonostratigraphic evolution of the Farsund Basin (Fig. 6), we now analyse the geometric and kinematic evolution of the upper-crustal fault populations. To achieve this, fault displacement backstrip- 

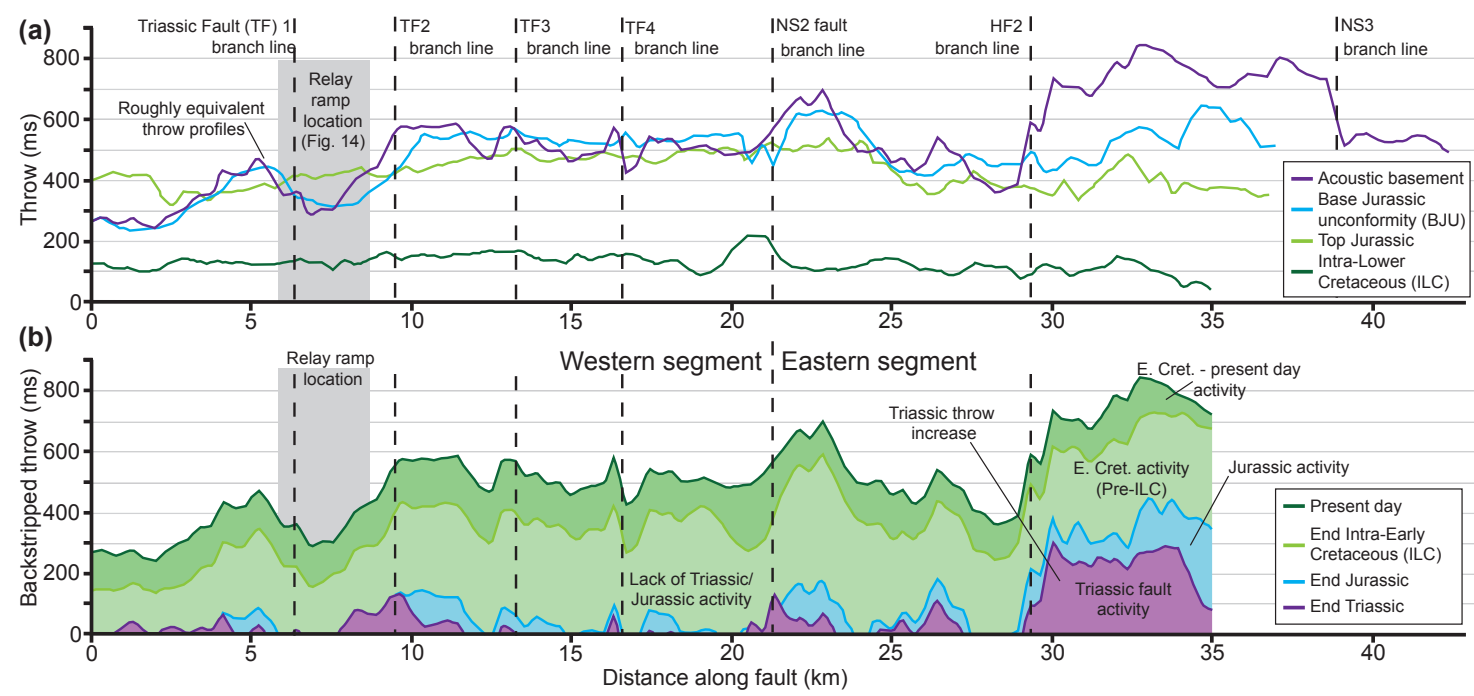

Figure 8. (a) Throw-length profiles calculated for major stratigraphic horizons across the Fjerritslev south fault showing the branch lines with cross-cutting faults. Note the similarity between the different stratigraphic horizons west of the HF2 branch line. (b) Backstripped fault profile for the Fjerritslev south fault showing Triassic activity east of the HF2 branch line but not elsewhere along the fault. Early Cretaceous fault activity is observed along the length of the fault.

ping was undertaken on the E-W-striking Fjerritslev north and Fjerritslev south faults (Figs. 7, 8). Additional throwlength plots were generated for the $\mathrm{N}-\mathrm{S}$-striking faults along the acoustic basement horizon; the faults are largely truncated by the BJU and display negligible throw at shallower, and therefore younger, stratigraphic levels (Fig. 3). Because the E-W faults tip out within the Lower Cretaceous succession, throw profiles were generated along the ILC horizon to help constrain the geometric and kinematic evolution of the faults during this time interval (Figs. 4, 5).

\subsection{Triassic fault activity}

Triassic extension was concentrated on $\mathrm{N}-\mathrm{S}$-striking faults, as well as relatively short, discrete segments of the E-Wstriking Fjerritslev north and south faults (Fig. 6a). The central segment of the Fjerritslev north fault, between its branch lines with NS1 and NS2, corresponds to a marked increase in throw (approximately $1000 \mathrm{~ms}$ TWT, $1300 \mathrm{~m}$ ) as measured along the acoustic basement horizon (Fig. 7a). Throw increases sharply at the branch lines with NS1 and NS2, with significantly larger throws (approximately $1500 \mathrm{~ms}$ TWT, $2000 \mathrm{~m}$ ) observed along the central segment compared to the western and eastern segments (approximately $500 \mathrm{~ms}$ TWT, $650 \mathrm{~m}$; Fig. 7a). Throw on NS1 is $\sim 950 \mathrm{~ms}$ TWT $(1700 \mathrm{~m})$ at the branch line with the Fjerritslev north fault, decreasing northwards to $\sim 500 \mathrm{~ms}$ TWT $(\sim 800 \mathrm{~m}$; Fig. $7 \mathrm{a})$; throw on NS2 at its branch line with the Fjerritslev north fault is $\sim 1200 \mathrm{~ms}$ TWT $(1700 \mathrm{~m})$, decreasing southwards to $\sim 600 \mathrm{~ms}$ TWT $(850 \mathrm{~m}$; Fig. 7a). NS1 and NS2 are eroded along the BJU; therefore, throw on these faults as calculated across the acoustic basement horizon largely represents throw accrued during the Triassic. NS2 shows relatively minor, post-Triassic activity (Figs. 5, 9).

Due to BJU erosion and the related absence of Triassic strata, the western segment of the Fjerritslev north fault only records post-BJU activity (Fig. 6a). Along the eastern segment of the fault, where Triassic strata are preserved, the same amount of throw occurs as along the western segment (approximately $500 \mathrm{~ms}$ TWT, $650 \mathrm{~m}$ ), indicating that both segments were only active post-BJU, likely during the Early Cretaceous (Fig. 7). Only the central segment of the Fjerritslev north fault shows any pre-Early Cretaceous activity, with throw backstripping showing that the central segment of the Fjerritslev north fault, along with NS1 and NS2, accrued $\sim 1000 \mathrm{~ms}$ TWT $(1300 \mathrm{~m})$ during the Triassic (Fig. 7b).

A further, discrete Triassic throw increase is observed along the eastern segment of the Fjerritslev south fault, located between HF2 in the west and NS3 to the east (Figs. 3, 8). To the west of HF2, throw along the acoustic basement, BJU and top Jurassic horizons remains relatively constant at $\sim 500 \mathrm{~ms}$ TWT $(\sim 800 \mathrm{~m})$, indicating a lack of pre-Early Cretaceous activity at this time (Fig. 8). However, between the HF2 and NS3 branch lines, throw increases to $\sim 700 \mathrm{~ms}$ TWT $(1300 \mathrm{~m})$, a $200 \mathrm{~ms}$ TWT increase above the BJU in this area, seemingly representing $\sim 200 \mathrm{~ms}$ TWT of Triassic throw in this area. Throw along the abutting HF2 and NS3 is similar, $\sim 200 \mathrm{~ms}$ TWT (500 m; Figs. 3, 5). Fault displacement backstripping indicates that, west of the branch line with HF2, the Fjerritslev south fault was initiated during the Early Cretaceous, and that only the eastern segment was active during the Triassic (Fig. 8). An Early Cretaceous age for initiation of faulting along the western part of the Fjerritslev 

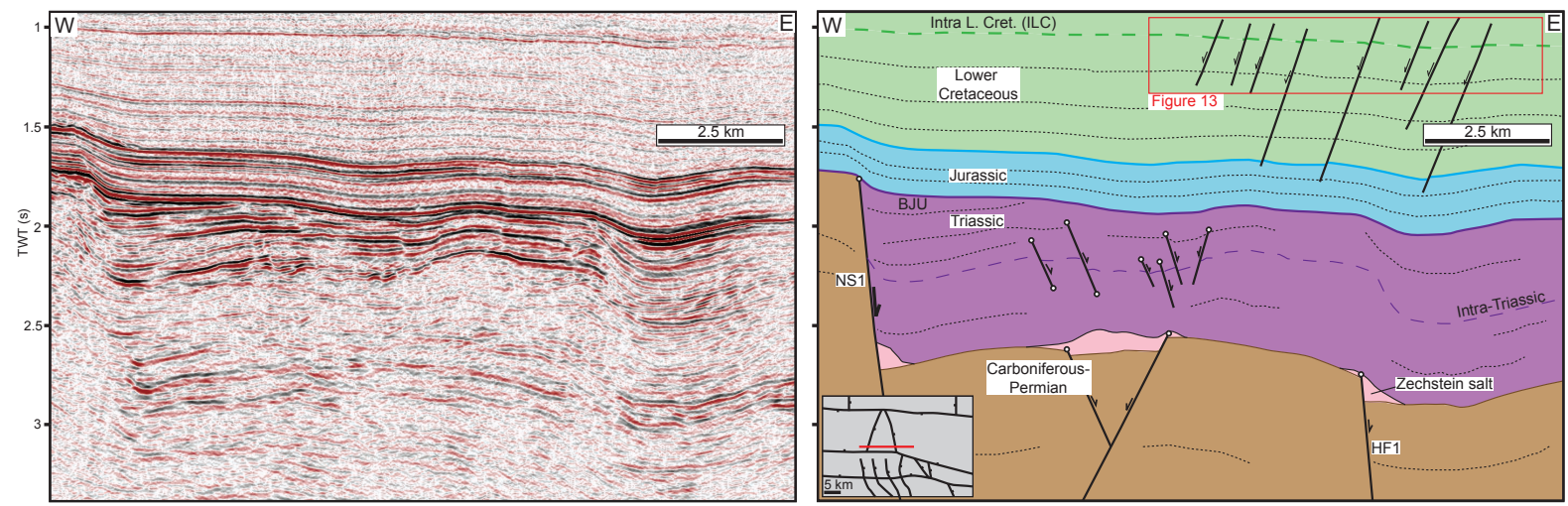

Figure 9. Interpreted and uninterpreted E-W-oriented 2-D seismic section located across NS1 and within the hangingwall of the Fjerritslev north fault. Triassic activity occurs across NS1, with little Early Cretaceous activity observed. Note the geometric similarities between NS1 and HF1 in this section, and NS2 and HF2 in Fig. 5. See Fig. 1c for location.

south fault is further supported by our prior observation that Carboniferous-Permian, Triassic and Jurassic strata do not thicken across it (Figs. 2, 4).

Segments of the Fjerritslev north and south faults, located between branch lines with $\mathrm{N}-\mathrm{S}$-striking faults, appear to have been active during the Triassic, at the same time as the N-Sstriking faults (Figs. 7b, 8). The main phase of activity along other parts of the E-W-striking faults occurred later, during the Early Cretaceous (Figs. 7b, 8b). One possible explanation for this relatively early, discrete Triassic activity could be that local segments of pre-existing E-W-striking faults are reactivated between the $\mathrm{N}-\mathrm{S}$-striking faults in response to an oblique stress field ("trailing segment reactivation" of Nixon et al., 2014). Although this model may explain the observed increase in throw along discrete $\mathrm{E}-\mathrm{W}$ fault segments (Fig. 7a), with both $\mathrm{N}-\mathrm{S}$ and $\mathrm{E}-\mathrm{W}$ faults active simultaneously and accruing throw as a geometrically and kinematically linked system, it requires a pre-existing E-W fault that was subsequently reactivated as the trailing segment. This requirement is inconsistent with our seismic-stratigraphic evidence, which indicates that such a fault was not present prior to the Triassic (Figs. 2, 4).

We suggest that a more feasible hypothesis is that the distinctive, discrete throw increases relate to passive, postformation lateral offset of the N-S-striking faults due to sinistral strike-slip motion along E-W-striking faults. Such a model envisages juxtaposition of the hangingwall and footwall of a N-S-striking fault across the $\mathrm{E}-\mathrm{W}$ fault, with a geometric consequence being an increase in throw along the $\mathrm{E}-$ $\mathrm{W}$ fault in the absence of any dip-slip extension. This model does not require Triassic activity along E-W-striking faults, in agreement with the Early Cretaceous timing of initiation for the Fjerritslev north and south faults (Figs. 7b, 8b). The local increases in throw would correspond to the difference in elevation between the hangingwall and footwall of the $\mathrm{N}-$ S-striking faults, which is essentially the throw accumulated on the N-S-striking faults during the Triassic (Figs. 7a, 10).
This model is supported by three observations. First, NS1 and NS2, and their respective hangingwall faults (HF1 and HF2), are geometrically similar, with HF1 and HF2 both showing folding and only minor offset of the acoustic basement surface (Figs. 5, 9). Second, NS1 and NS2, along with HF1 and HF2 located within their respective hangingwalls, are laterally offset by approximately $10 \mathrm{~km}$ (Figs. 5, 9). Finally, NS1 and NS2 display similar values of throw at their branch lines with the Fjerritslev north fault $(\sim 1000 \mathrm{~ms}$ TWT) to the discrete increase in throw that occurs between the intersections (Fig. 7a). This is consistent with the increase in throw being equivalent to the throw accrued along $\mathrm{N}-\mathrm{S}$ faults during the Triassic.

Further evidence for sinistral strike-slip activity is observed at the northern margin of the basin, along the EW-striking Farsund north fault, implying offset of the NS1 and west Varnes Graben (WVG) fault (Figs. 1c, 10). A shallow footwall and deeper hangingwall, related to Early Cretaceous extensional activity, are identified along the Farsund north fault, despite it being associated with a complex zone of deformation (Fig. 11). A key observation we make is that Carboniferous-Permian and Triassic strata are preserved in the footwall of the Farsund north fault, yet are eroded by the BJU in its hangingwall (Fig. 11). The footwall of the E-W Farsund north fault also corresponds to the hangingwall of the N-S-striking WVG fault, whereas the hangingwall of the Farsund north fault corresponds to the footwall of the NS1 fault (Figs. 10c, 11). We propose that, in the same way as we interpret to the south, the N-S-striking WVG and NS1 faults initially represented a single, through-going structure, with erosion along its footwall occurring due to the BJU. This fault was then offset by $\sim 10 \mathrm{~km}$ of sinistral strike-slip motion. This strike-slip activity juxtaposed the original hangingwall and footwall of the N-S fault across the Farsund north fault, resulting in the complex and perhaps somewhat unusual structural and stratal geometries we observe (Fig. 11). 
(a) Triassic - pre-strike-slip faulting

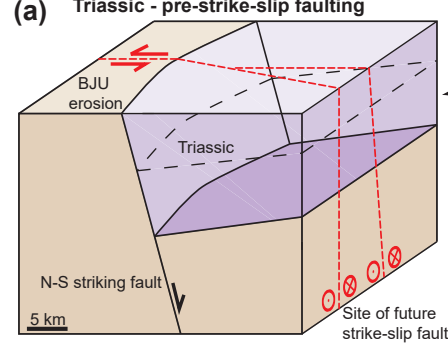

(b) Pre-E. Cret $\begin{aligned} & \text { Hangingwall-footwall } \\ & \text { juxtaposition }\end{aligned}$

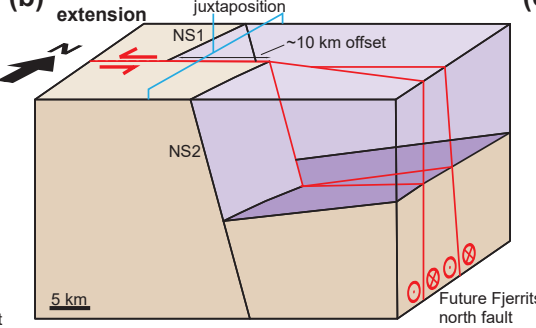

(c)

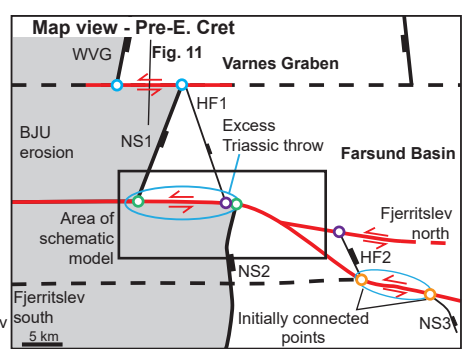

Figure 10. (a) Schematic diagram showing Triassic activity along N-S-striking faults. (b) Schematic diagram showing the resultant fault geometries and associated hangingwall-footwall juxtaposition as a result of the sinistral offset of the N-S-striking fault. (c) Map showing the geometry of the strike-slip system within the Farsund Basin prior to the Early Cretaceous. The black box shows the location of the schematic model showing hangingwall-footwall juxtaposition, with blue ovals showing areas of excess Triassic throw (see Figs. 7, 8).
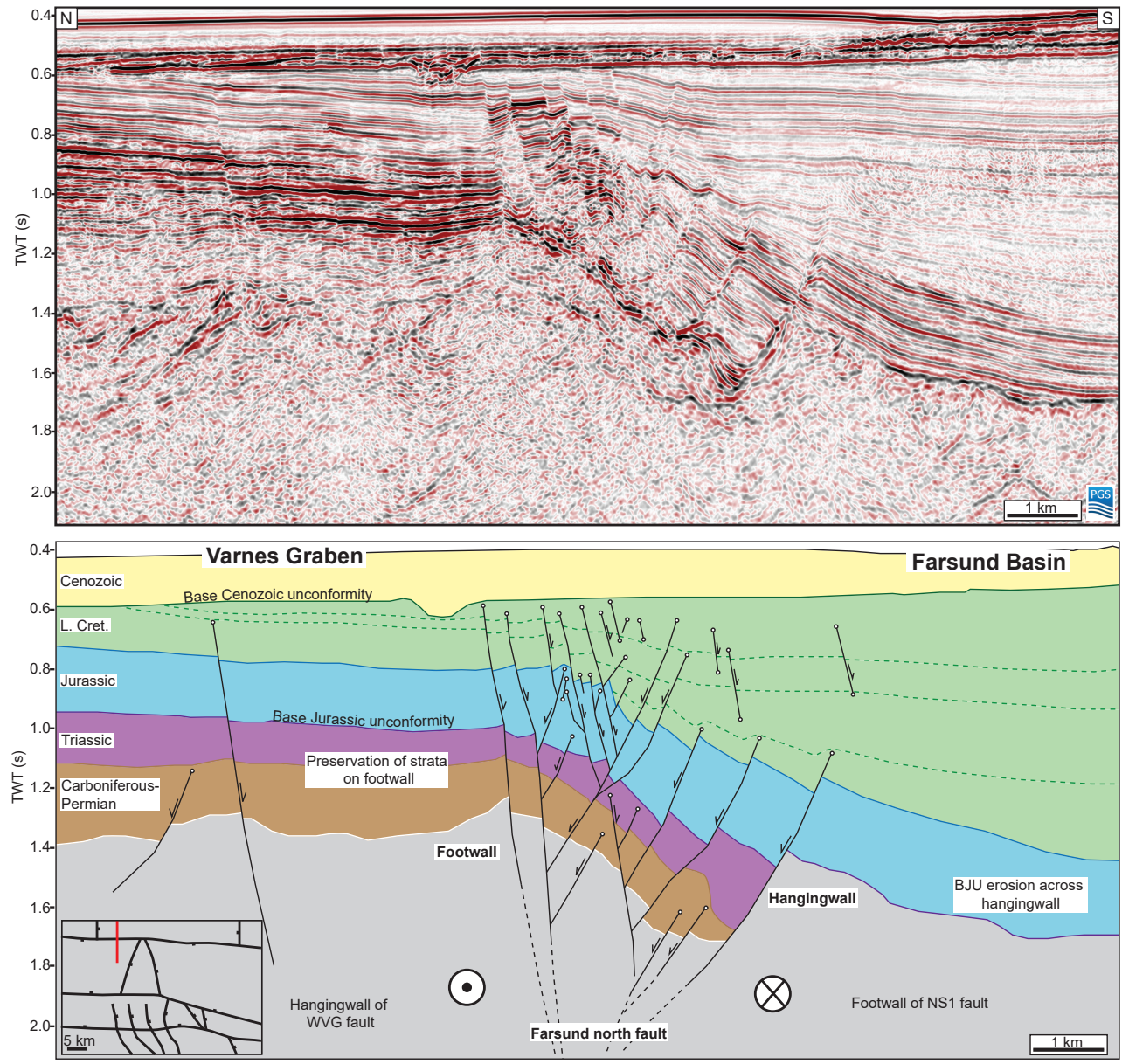

Figure 11. Interpreted and uninterpreted N-S-oriented 2-D seismic section across the Farsund north fault. Preservation of CarboniferousPermian and Triassic strata across the footwall of the Farsund north fault with concomitant erosion across the hangingwall represents the same hangingwall-footwall juxtaposition demonstrated in Fig. 10. See Figs. 1c, 10 for location.

Having presented geometric observations showing strikeslip motions along E-W-striking faults within the Farsund Basin, we now determine the timing of this activity. Based on the geometric and kinematic evidence outlined above (Figs. 5, 7, 9, 11), we propose that the WVG, NS1 and NS2 faults initially formed a singular N-S-striking fault during the Triassic, with HF1 and HF2, and HF2 and NS3 forming further, through-going, $\mathrm{N}-\mathrm{S}$-striking faults at this time. These faults were then offset along a series of E-W-striking, sinistral strike-slip faults, which appear to, in places, follow 
the location of, and may represent precursors to, the presentday E-W-striking faults (Fig. 10b). This strike-slip activity must have occurred after the extensional activity along the N-S-striking faults during the Triassic (Fig. 6). Relatively smooth throw profiles and low displacement gradients along the Fjerritslev north and south faults on supra-BJU horizons (top Jurassic and ILC; Figs. 7, 8), and the relatively isopachous Jurassic interval across the Farsund north fault (Fig. 11), indicates that any strike-slip activity must have occurred prior to the deposition and preservation of Jurassic strata (Figs. 7, 8), most likely during the Early-Middle Jurassic, a period of either non-deposition or erosion by the BJU. More precise constraints on this age and evidence for any deformation associated with the activity are not possible given erosion along the BJU.

\subsection{Late Jurassic - Early Cretaceous fault activity}

Following Triassic extensional activity along N-S faults and strike-slip activity during the Early to Middle Jurassic, E-Wstriking faults were active during the Late Jurassic - Early Cretaceous (Figs. 3, 6). Here, we detail the geometric and kinematic behaviour of the Fjerritslev north and south faults in response to this tectonic event.

\subsubsection{Fjerritslev north fault}

Fault displacement backstripping indicates that the Fjerritslev north fault started to accommodate considerable amounts of extension during the Early Cretaceous (Fig. 7). At the ILC structural level, the central and western segments of the fault are expressed as a series of left-stepping enechelon fault segments, with basinward-facing monoclines in their hangingwall (Fig. 12). Along the western segment of the fault, each individual en-echelon segment is $1-2 \mathrm{~km}$ long and strikes at $\sim 099^{\circ}$, a clockwise rotation of $11^{\circ}$ from that of the overall E-W strike $\left(088^{\circ}\right)$ characterising the fault at deeper levels (Fig. 12). Along the central segment of the fault, the en-echelon segments are each $3-5 \mathrm{~km}$ long (Fig. 12). The WNW-ESE-striking eastern segment lacks clear segmentation (Fig. 12).

En-echelon faults, geometrically similar to those observed along the Fjerritslev north fault (Fig. 12), may form through the reactivation of a fault under a stress regime oblique to its orientation (Giba et al., 2012; Grant and Kattenhorn, 2004; Naylor et al., 1986; Richard, 1991; Swanson, 2006; Withjack et al., 2017) or pure dip-slip activity within mechanically anisotropic sequences (Jackson and Rotevatn, 2013; Schöpfer et al., 2007). However, based on the apparent lack of major lithological changes along strike and the fact that the degree of en-echelon segmentation does change, we suggest that the fault geometry and the degree of obliquity experienced controls the degree of en-echelon segmentation rather than lithology. Grant and Kattenhorn (2004) show that oblique slip along a buried normal fault initially leads to the formation of a fault-parallel monoclinal fold at the surface. Further slip leads to fold breaching and preservation of a hangingwall monocline, with fault propagation associated with upward bifurcation of a single slip plane to form a series of en-echelon segments (see also Giba et al., 2012; Withjack et al., 2017).

The strike of the Fjerritslev north fault changes east of the branch line with NS2, from broadly E-W along the central segment $\left(086^{\circ}\right)$ to more WNW in the east, with this latter segment associated with a major depocentre (Fig. 12). Along the inside of the bend defined by this change in strike, WNW-striking faults, broadly parallel to the main structure, are observed within the footwall of the Fjerritslev north fault (Figs. 3, 12). These faults are geometrically similar to shortcut faults developed between differently oriented fault segments in the analog models of Paul and Mitra (2015). The outer bend (i.e. hangingwall) of the Fjerritslev north fault is characterised by an array of small ( $\sim 12 \mathrm{~ms}$ TWT, $15 \mathrm{~m}$, throw) faults that strike NE, perpendicular to the main fault trace (Fig. 13), and which dip NW (Fig. 9). The faults are arranged into two main groups, situated at each of the apexes of the fault bend (Fig. 13), with the larger faults situated in the east adjacent to a major hangingwall depocentre (Figs. 12, 13). These structures are, at last superficially, geometrically similar to "hangingwall release faults" (sensu Destro, 1995; Stewart, 2001), which form as the hangingwall stretches along strike so as to accommodate along-strike variations in fault displacement. However, we note that maximum throw on these faults occurs outboard of the main fault (Figs. 9, 13) and not at the branch line as would be expected for hangingwall release faults. Instead, we propose that these hangingwall faults form in response to outboard stretching, accommodating extension around the convex bend in the fault plane, between the E-W-striking, more oblique, central and western fault segments, and the more optimally oriented eastern segment (Figs. 12, 13).

\subsubsection{Fjerritslev south fault}

Like the Fjerritslev north fault, the Fjerritslev south fault was active during the Early Cretaceous (Figs. 6c, 8). However, a key observation is that, at the ILC structural level, the two faults differ markedly in their structural style; the Fjerritslev south fault is more linear than the strongly segmented Fjerritslev north fault (Fig. 12). The Fjerritslev south fault is composed of several $5-10 \mathrm{~km}$ long strands, separated by footwall breached relay ramps and branch lines with pre-existing Triassic faults (Fig. 12). The presence of these breached relay ramps is not immediately obvious, although they can be inferred through the presence of composite monoclines (Figs. 12, 14). These composite monoclines comprise one fold hinge situated above the main fault trace, and a further fold hinge situated above the abandoned fault trace (Fig. 14). An additional composite monocline is present immediately west of the Fjerritslev south fault's branch line with NS2, 


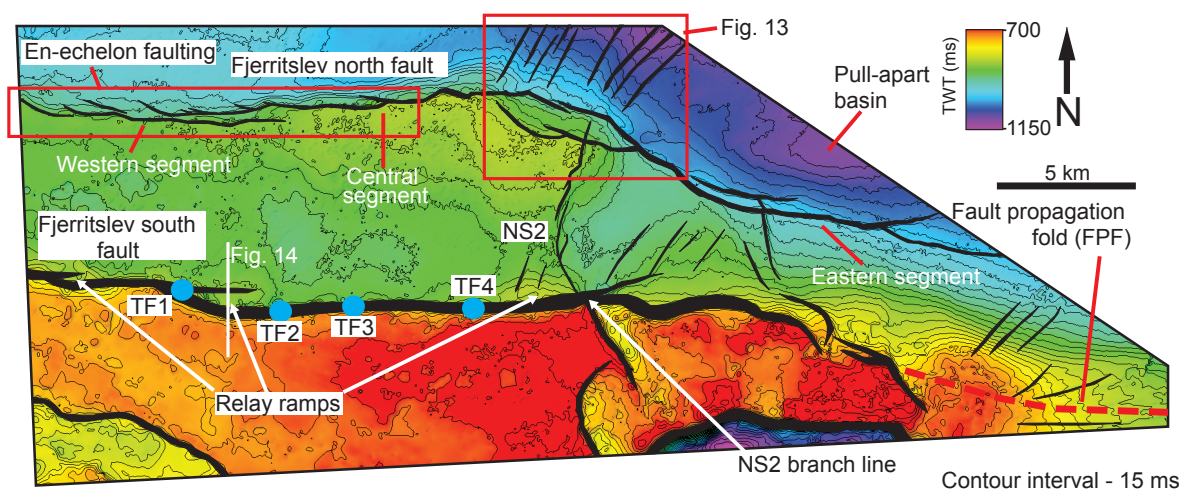

Figure 12. Two-way time structure map of the intra-Lower Cretaceous horizon (see Figs. 4, 5 for surface in section). The Fjerritslev north fault shows clear en-echelon segmentation along its western segment and a deepening of the surface in its hangingwall to the northeast. Intersections of underlying Triassic N-S-striking faults with the Fjerritslev south fault at deeper stratigraphic levels are indicated by blue circles.
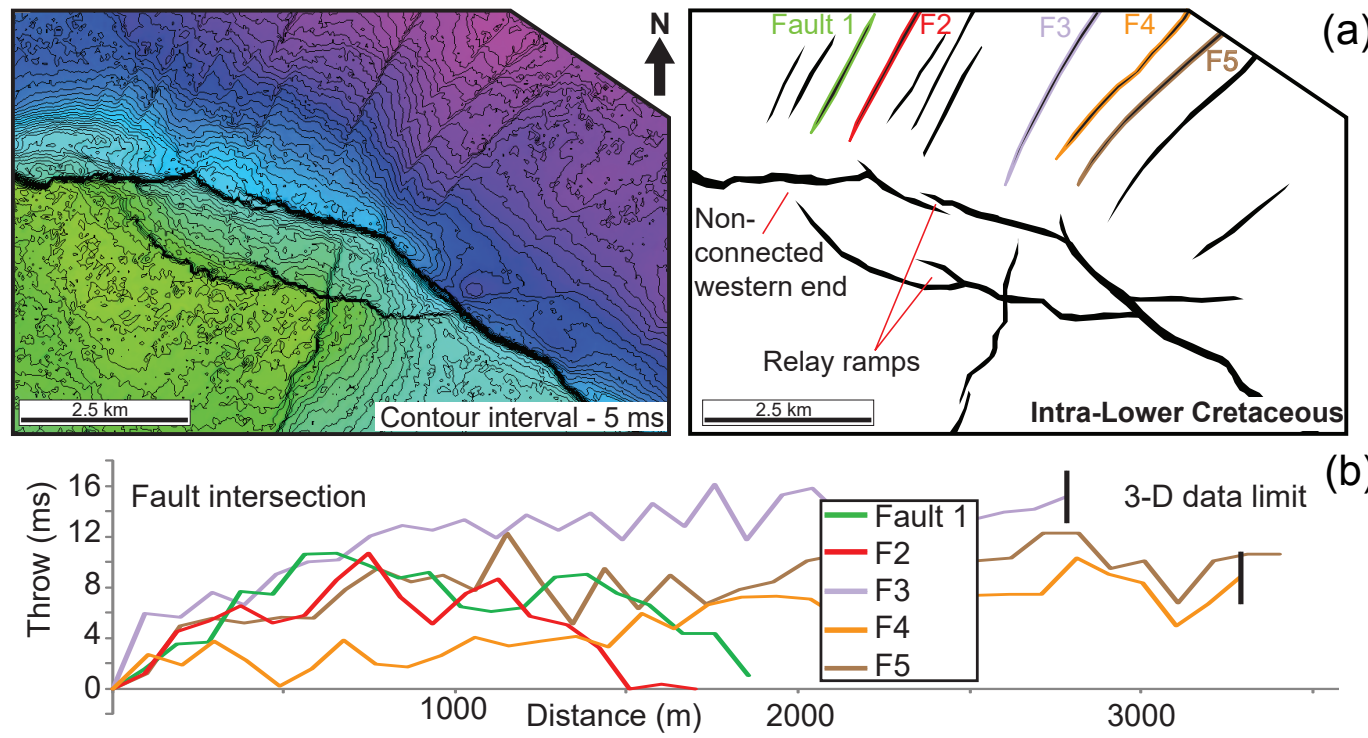

(b)

Figure 13. (a) Interpreted and uninterpreted fault geometries of the bend in the Fjerritslev north fault at the ILC stratigraphic horizon. A series of minor, NE-striking faults are present around the outside of the bend, perpendicular to the main fault trace. For the colour bar, see Fig. 12. (b) T-x profiles for the outer-bend faults as calculated for the ILC stratigraphic horizons. Throw maxima are observed outboard of the main Fjerritslev north fault trace.

potentially indicating some segmentation and a relay ramp in this location.

The Fjerritslev south fault was initiated during the Early Cretaceous, accruing up to $500 \mathrm{~ms}(600 \mathrm{~m})$ of throw along its entire length (Fig. 8). West of HF2, no precursor fault is present, with the fault showing only Early Cretaceous activity (Figs. 4, 8). The apparent Triassic throw east of HF2 is attributed to an Early-Middle Jurassic stage of strike-slip activity with no Triassic dip-slip extension actually having occurred (Fig. 8b). Extensional activity along the Fjerritslev south fault was initiated during the Early Cretaceous, with the fault represented by a series of segments partitioned by pre-existing, N-S-striking faults (NS2 and TF1, Fig. 12). An increase and subsequent decrease in the relief of the acoustic basement surface across the footwall of the fault, to the east of NS2, may represent the eastern segment of the fault (Fig. 3). Further segments are observed west of TF1, separated by footwall breaching relay ramps and associated composite monoclines (Fig. 14).

In summary, based on (i) the left-stepping en-echelon segmentation observed along the western segment (Fig. 12), (ii) the development of outer-bend faults in response to fault plane convexities associated with changes in strike (Fig. 13) and (iii) the development of a major depocentre within the hangingwall of the WNW-striking eastern segment, we propose that the Fjerritslev north fault was obliquely reactivated 

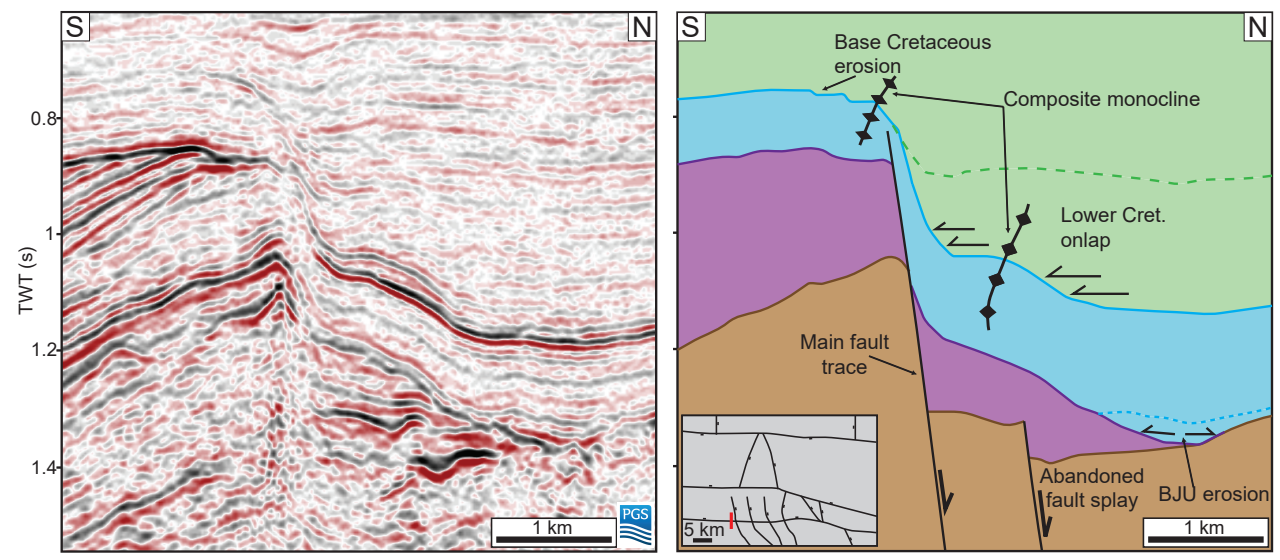

Figure 14. Interpreted and uninterpreted N-S-oriented seismic section (from 3-D seismic volume) across the Fjerritslev south fault. The section shows the presence of a composite monocline and associated underlying relay ramp.

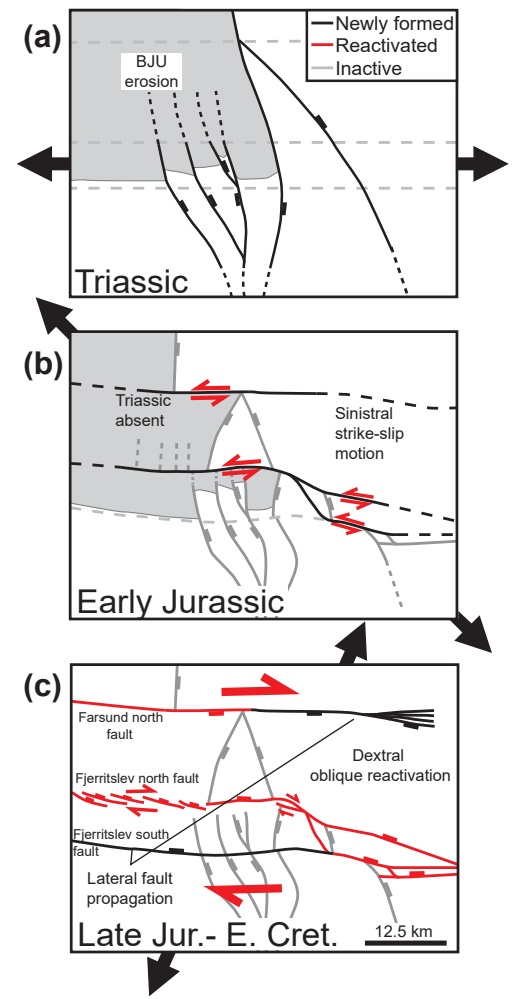

Figure 15. Schematic model showing the fault geometries and kinematics during (a) Triassic E-W extension; (b) Early-Middle Jurassic sinistral strike-slip activity; and (c) Early Cretaceous dextral transtension.

in a dextral sense during the Early Cretaceous (Fig. 15c). The western part of the Fjerritslev south fault was initiated as a new structure at this time under the same stress regime, propagating westwards away from the prior strike-slip fault initially constrained between HF2 and NS3 (Figs. 10c, 15c).

\section{Discussion}

\subsection{Geometric and kinematic development of multiphase rift-related fault networks during non-coaxial extension}

We have determined the geometric and kinematic evolution of upper-crustal faults within the Farsund Basin. Triassic N$\mathrm{S}$-striking faults were offset by a series of E-W-striking, sinistral strike-slip faults during the Early-Middle Jurassic (Figs. 10a, b, 15a). Strike-slip systems in nature and in experimental models often display anastomosing, duplex geometries, where strain is distributed along a series of discrete structures that link in both strike and dip directions (e.g. Chamberlain et al., 2014; Cheng et al., 2017; Corti and Dooley, 2015; Dooley and Schreurs, 2012; Mann, 2007; Naylor et al., 1986; Richard et al., 1995; Scholz et al., 2010; Schreurs, 2003; Vauchez and Tommasi, 2003; Wu et al., 2009). However, due to BJU erosion, we can only confirm prior strikeslip activity between the laterally offset $\mathrm{N}-\mathrm{S}$-striking faults, i.e. NS1 and NS2 (Figs. 7, 10), HF2 and NS3 (Figs. 8, 10), and WVG and NS1 (Figs. 10c, 11). Where we know strikeslip faulting occurred, i.e. between the offset $\mathrm{N}-\mathrm{S}$ faults, the strike-slip faults correspond to the same location as Early Cretaceous normal faults, i.e. the Fjerritslev north and Farsund north faults (Fig. 15b, c), observed at the present day, potentially indicating that these later extensional faults reactivated the prior strike-slip ones. However, the Fjerritslev south fault west of HF2 cannot have reactivated an older strike-slip fault. The strike-slip fault offsetting HF2 and NS3 does not share the same location as the Fjerritslev south fault west of HF2, as the lack of offset of NS2 would imply an unrealistically steep displacement gradient (Peacock and Sanderson, 1991; Fig. 15b). Instead, we propose that, in this location, the strike-slip fault strikes NW-SE, following the location of HF2 (Fig. 15b), and joining with the strike-slip 
fault between NS1 and NS2 (later reactivated as the Fjerritslev north fault).

Fault displacement backstripping (Figs. 7, 8) and seismic stratigraphic observations (Figs. 2, 4) indicate an Early Cretaceous onset of extension for the E-W-striking faults. This is consistent with our interpretation of Early-Middle Jurassic strike-slip activity along E-W-striking faults, with these faults experiencing no dip-slip motions prior to the Early Cretaceous. Apparent Triassic throw along the central segment of the Fjerritslev north fault and the eastern segment of the Fjerritslev south fault occurred through the passive juxtaposition of different structural levels across the fault, as opposed to active dip-slip faulting. This study shows that, particularly in areas of non-collinear faulting and oblique stress fields, care needs to be taken when interpreting fault kinematics from T-x profiles alone. In such instances, further lines of evidence, such as the presence of synkinematic strata, are required to confirm extensional fault activity.

En-echelon fault segmentation, such as that observed along the Fjerritslev north fault at the ILC structural level (Fig. 12), may form due to the oblique reactivation of a preexisting fault (Giba et al., 2012; Grant and Kattenhorn, 2004; Lăpădat et al., 2016; Withjack et al., 2017). In the case of the Fjerritslev north fault, this is likely to be the pre-existing strike-slip fault (Figs. 10c, 15). Conversely, the Fjerritslev south fault, which was also active during the Early Cretaceous, is more linear and not obviously segmented. In addition, its western segment does not have the same strike as the pre-existing strike-slip fault (Fig. 15b). The Fjerritslev south fault instead appears to propagate westwards away from the prior strike-slip fault in the east as a newly formed structure, rather than simply reactivating a pre-existing one - hence the difference in structural style between it and the Fjerritslev north fault (Figs. 8, 15). The Farsund north fault, which also shows only Early Cretaceous extensional activity (Figs. 2, 11 ), appears to show a complementary eastwards propagation along the northern margin of the basin (Fig. 15c). Relay ramps along the Fjerritslev south fault appear to correspond to the intersections with the N-S-striking faults (TF14). These N-S-striking faults were active during the Triassic (Fig. 6a) and were not offset during Early Jurassic sinistral strike-slip activity (Fig. 15b). Therefore, as the Fjerritslev south fault was initiated as a new structure and propagated westwards from HF2 during the Early Cretaceous (Fig. 15c), the presence of the pre-existing TF1-4 may have segmented the newly forming Fjerritslev south fault (Fig. 12). The geometry and kinematic history of the Fjerritslev North fault during the Early Cretaceous, in particular the development of en-echelon segmentation and formation of a major depocentre in the more optimally oriented eastern fault segment, indicate that although dominant fault motion within the basin is extensional during the Early Cretaceous, there is a significant component of oblique slip (e.g. de Paola et al., 2005; Grant and Kattenhorn, 2004; Naylor et al., 1986; Richard et al., 1995; Fig. 15c). In the east of the basin, rapid subsi- dence may locally have been accentuated by salt mobilisation (Christensen and Korstgård, 1994).

\subsection{Relation of the STZ to the regional tectonic setting}

We have determined the kinematic history of upper-crustal faults during multiple tectonic events, which we propose link to, and reflect activity along, the STZ at sub-crustal depths. Here, we examine the driving forces behind these tectonic events. Due to the fixed E-W orientation of the upper-crustal expression of the STZ relative to later tectonic events, we are able to use the observed reactivation style to infer the prevailing regional stress field at that time.

During the Carboniferous-Permian, dextral transtension and transpression occurred on a series of NW-trending faults along the STZ and TTZ (Fig. 16a; e.g. Erlström et al., 1997; Liboriussen et al., 1987; Michelsen and Nielsen, 1993; Mogensen, 1994), including along the Fjerritslev fault system to the east of the basin (Hamar et al., 1983; Mogensen, 1994; Skjerven et al., 1983). We document no such activity in the Farsund Basin (Figs. 2, 4). Sinistral motion is also proposed along the Skagerrak Graben at this time (Fanavoll and Lippard, 1994; Lie and Husebye, 1994; Mogensen, 1994), which, when combined with dextral motion along the STZ, results in net $\mathrm{E}-\mathrm{W}$ extension, accommodating $\mathrm{N}-\mathrm{S}$ compression from the Variscan Orogeny to the south (Fig. 16a). As such, we may not expect any extensional activity along the E-W faults within the Farsund Basin. N-S-striking faults in and around the Farsund Basin do not appear to be related to the STZ; instead, these faults appear to form the northern continuation of the Horn Graben, which formed in response to Permian-Triassic E-W-directed extension (Nielsen, 2003; Vejbæk, 1990).

Throughout the Mesozoic, both sinistral (Jones et al., 1999; Liboriussen et al., 1987; Norling and Bergström, 1987; Pegrum, 1984; Sivhed, 1991) and dextral (Bergerat et al., 2007; Erlström et al., 1997; Graversen, 2009; Hansen et al., 2000; Michelsen and Nielsen, 1993; Mogensen, 1995; Mogensen and Korstgård, 2003) strike-slip and oblique motions have been documented at various locations along the STZ. Sinistral strike-slip activity along an E-W-trending structure, such as observed during the Early-Middle Jurassic (Fig. 16c), could be driven by regional E-W- to NWSE-oriented extensional stress fields. Potential regional driving mechanisms during the Early-Middle Jurassic include (i) localised extension north of the STZ within the Skagerrak Graben (Ro et al., 1990; Vejbæk, 1990), (ii) regional stresses relating to the inflation of the middle North Sea thermal dome (Rattey and Hayward, 1993; Underhill and Partington, 1993) or (iii) far-field stresses relating to the opening of the Atlantic and Tethyan oceans to the south (Vissers et al., 2013; Ziegler, 1990; Ziegler and Stampfli, 2001). The Skagerrak Graben was inactive throughout the Jurassic and was furthermore decoupled from the STZ at this time (Ro et al., 1990); accordingly, localised extension along the Skagerrak Graben 
could not have driven the observed strike-slip activity. The influence of the middle North Sea thermal dome was felt in the Farsund Basin during the Early-Middle Jurassic and associated stresses would be localised south of, and potentially buffered by, the STZ (Underhill and Partington, 1993; Fig. 16c). Although it is difficult to envisage how stresses arising from broad, regional inflation result in strike-slip activity, this still may represent a possible explanation, particularly if the uplift is buffered at the STZ (Fig. 16c). A further possibility is that the strike-slip activity is related to far-field stresses transmitted along the Tornquist Zone associated with ocean formation to the south (e.g. Coward et al., 2003; Vissers et al., 2013; Ziegler and Stampfli, 2001).

Around the Early-Middle Jurassic, the incipient PiemontLiguria Ocean was situated south of the STZ, between the northwards subducting Tethys to the east and the central Atlantic to the west (Coward et al., 2003; Vissers et al., 2013; Ziegler, 1990; Ziegler and Stampfli, 2001). Seafloor spreading within the Piemont-Liguria Ocean was initiated at around $170 \mathrm{Ma}$, during the Middle Jurassic, with the ocean basin and prior rifting buttressed to the east at the TTZ (Vissers et al., 2013). Continental extension occurred during the Early-Middle Jurassic, prior to seafloor spreading, and was associated with sinistral strike-slip motion along the TTZ (Vissers et al., 2013; Fig. 16). Compressional forces arising from the subduction of the Tethys to the west may have also led to sinistral strike-slip motions being transmitted along the NW-trending Tornquist Zone, potentially reaching the Farsund Basin (see Fig. 7 in Ziegler, 1990; Fig. 16c). The Tornquist Zone may have acted as a proto-transform structure, representing an ultimately failed link between the North Atlantic rift system to the northwest and the Tethys to the southeast, similar to the transform fault between the Iberian Peninsula and central Europe (see Fig. 7 in Vissers et al., 2013; Fig. 16c). One implication of this model is the occurrence of sinistral motion along the whole of the Tornquist Zone at this time, a requirement not necessitated by the thermal dome hypothesis (Fig. 16c). Based on our data, we are unable to comment on whether this activity occurred along the structure to the east, although some sinistral activity is observed to the west (Jones et al., 1999; Pegrum, 1984; Skjerven et al., 1983).

Dextral transtensional activity occurred within the Farsund Basin during the Early Cretaceous (Figs. 12, 13, 15), as observed elsewhere along the STZ at this time (Bergerat et al., 2007; Michelsen and Nielsen, 1993; Mogensen and Jensen, 1994). Based on the easterly trend of the STZ in this location, the driving regional stress field could be extension and orientated approximately E-W to NE-SW (Fig. 15). Regional extension occurred across the North Sea during the Late Jurassic - Early Cretaceous and was oriented E-W to NE-SW in the central and southern North Sea (Coward et al., 2003; Rattey and Hayward, 1993; Underhill and Partington, 1993), and E-W to NW-SE in the northern North Sea (Bartholomew et al., 1993; Bell et al., 2014; Brun and Tron,

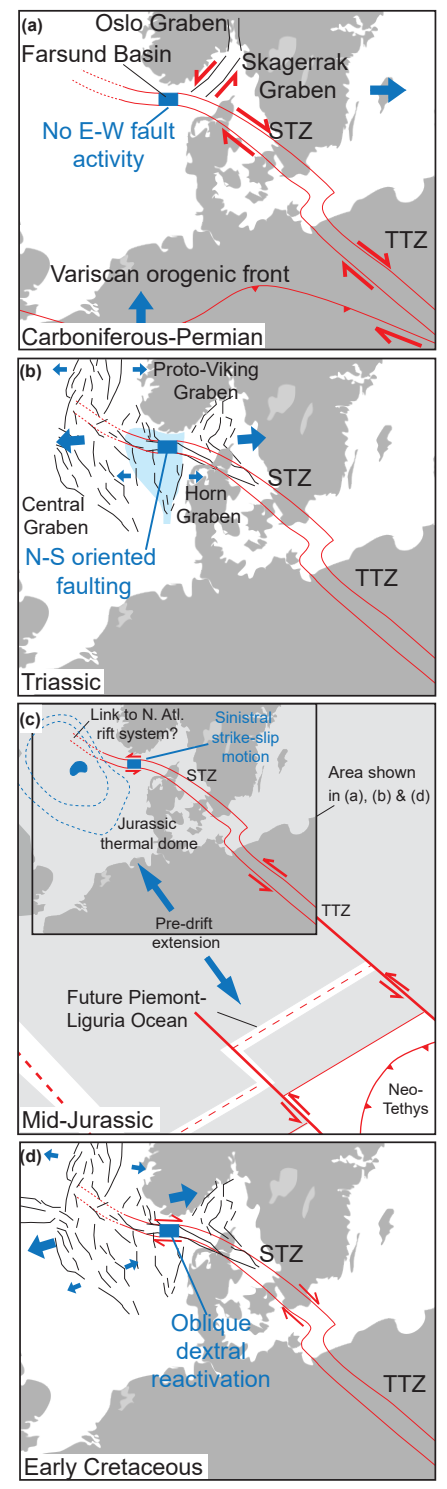

Figure 16. (a) Schematic model showing the regional tectonic setting during the Carboniferous-Permian and linking this to the lack of observed activity within the Farsund Basin. (b) Schematic model linking the regional Triassic E-W-oriented extension to the Triassic N-S-oriented faulting within the Farsund Basin. (c) Wider-scale schematic model to highlight potential causative mechanisms for Early-Middle Jurassic sinistral strike-slip activity in the Farsund Basin. Viable driving mechanisms include the uplift of the middle North Sea thermal dome and the opening of the Piemont-Liguria Ocean. (d) Schematic model linking the local Early Cretaceous dextral transtension observed within the Farsund Basin to regional E-W to NE-SE extension occurring at this time.

1993). Oblique dextral reactivation of $\mathrm{E}-\mathrm{W}$-striking faults indicates that NE-SW-to-E-W extension, associated with activity within the Central Graben, was prevalent at this time within the Farsund Basin (Fig. 16d). 


\subsection{Nature and reactivation of lithospheric lineaments}

We have shown that the upper-crustal part of the STZ was repeatedly reactivated in a range of different tectonic styles, which we have linked to regional tectonic events, prevailing stress fields, and potentially broader geodynamic context (Fig. 16). Here, we discuss how such a contrast in lithospheric thickness and properties at depth (e.g. Cotte and Pedersen, 2002; Hossein Shomali et al., 2006; Kind et al., 1997) is able to influence rift development within the upper crust.

Changes in lithospheric thickness associated with prior phases of rifting or different continental blocks have previously been shown to influence the development of rift systems (Autin et al., 2013; Brune et al., 2017; Corti, 2009). In addition, numerous studies show that strike-slip and oblique fault systems can dissect the whole lithosphere and are often associated with pervasive fabrics within mantle lithosphere (Tommasi and Vauchez, 2001; Vauchez and Tommasi, 2003; Wylegalla et al., 1999). Examples from the Great Glen Fault, UK (Klemperer and Hobbs, 1991; McBride, 1995), the Transbrasiliano fault zone, onshore Brazil (Daly et al., 2014), and the San Andreas fault system, USA (Chamberlain et al., 2014), represent crustal-terrane separating fault systems that extend down to at least the base of the crust and, in many cases, into the sub-crustal lithosphere (Vauchez and Tommasi, 2003). These lithosphere-scale structures are often oriented oblique to regional tectonic events and are thus subjected to oblique stresses; as such, they are often reactivated in a transpressional or transtensional manner, resulting in complex rifts at upper-crustal levels (e.g. Bergerat et al., 2007; Calignano et al., 2017; Cheng et al., 2017; Corti and Dooley, 2015; Holdsworth et al., 2001; Le Breton et al., 2013; Underhill and Brodie, 1993; Vauchez and Tommasi, 2003).

The E-trending Farsund Basin and STZ represent a further example of a lithosphere-scale structure (Fig. 2). Lassen and Thybo (2012) propose the STZ formed as an Ediacaran rift system during the breakup of Rodinia. Montalbano et al. (2016) note a sinistral phase of motion along the present-day trend of the STZ around this time, indicating that the structure must have existed in some form at this time. Although the STZ appears to have been present in some form since the Late Proterozoic (Lassen and Thybo, 2012; Montalbano et al., 2016), its upper-crustal component appeared to have been established during the CarboniferousPermian as a lithosphere-scale strike-slip system, exploiting the change in lithospheric thickness and properties at depth (Erlström et al., 1997; Lassen and Thybo, 2012). The localised reactivation of this structure appears to buffer the cratonic lithosphere of Baltica against the regional tectonic events that affect the amalgamated terranes of central $\mathrm{Eu}-$ rope (see Berthelsen, 1998; Mogensen and Korstgård, 2003). Berthelsen (1998) proposed that the Fjerritslev Fault system forms a NE-dipping detachment that shields the cratonic lithosphere of Baltica. Although our data are unable to confirm details of this hypothesis, we do note a connection between the sub-crustal and upper-crustal components (Fig. 2), which may concentrate deformation within the STZ, thus leaving the cratonic lithosphere of Baltica relatively undeformed. As the orientation of this lithosphere-scale structure is fixed relative to the later tectonic events (Babuška and Plomerová, 2004; Cotte and Pedersen, 2002), yet is weak enough to be repeatedly reactivated throughout these events, seemingly regardless of orientation, the style of reactivation of the upper-crustal component can be inverted to better understand the regional stress field that has affected the North Sea throughout these multiple tectonic events.

\section{Conclusions}

In this study, we use the geometric and kinematic evolution of a complex upper-crustal fault population to better understand the kinematic behaviour of a linked deeper structure, the lithosphere-scale Sorgenfrei-Tornquist Zone. We find the following:

1. The E-W faults that define the margins of the Farsund Basin form a linked system both laterally and at depth. These represent a crustal-scale fault system and are interpreted to extend through the Moho to the change in lithospheric thickness and properties representing the Sorgenfrei-Tornquist Zone within the sub-crustal lithosphere. Together, this lithospheric step and the uppercrustal rift system form the lithosphere-scale STZ.

2. The southern margin of the Farsund Basin is characterised by $\mathrm{N}-\mathrm{S}$ - and $\mathrm{E}-\mathrm{W}$-striking fault populations. No activity is observed within the Farsund Basin during Carboniferous-Permian activity, in contrast to elsewhere along the STZ. Extension across N-S-striking faults occurs in the Triassic, with E-W-striking faults beginning to accommodate extension during the Late Jurassic - Early Cretaceous.

3. Sinistral strike-slip motion is observed along a number of E-W-striking faults during the Early-Middle Jurassic, acting to offset pre-existing N-S faults. This results in the juxtaposition of the hangingwall and footwall of these pre-existing faults, creating apparent throw along the fault, without any extension having occurred. This represents a previously undocumented phase of activity across the North Sea and may be linked to far-field stresses arising from the opening of oceanic basins to the south, or the inflation of the mid-North Sea thermal dome to the west.

4. Sinistral strike-slip activity is succeeded during the Early Cretaceous by the oblique dextral reactivation and lateral propagation of E-W-striking faults. This phase of activity is linked to the regional NE-SW-oriented regional Late Jurassic - Early Cretaceous extension and 
resulted in the formation of the present-day morphology of the Farsund Basin.

5. The lithosphere-scale STZ represents a long-lived lithospheric weakness that is preferentially reactivated in an oblique manner during later tectonic events, with the style of reactivation being dependent on the regional stress field. The observed style of reactivation can offer insights into the prevailing stress field at various points throughout the protracted history of the STZ, in some cases highlighting previously unknown tectonic events.

6. We find that structures within the sub-crustal lithosphere are often associated with complex upper-crustal rift systems and may exert a strong influence over their geometry and development. Regional stress fields at oblique angles to these structures result in oblique reactivation of structures within the upper crust. The geometric and kinematic evolution of fault populations within these upper-crustal structures is not only able to offer insights into the kinematic behaviour of the structures within the sub-crustal lithosphere but is also inherently linked to the larger-scale regional stress field at the time.

Data availability. Seismic data analysed in this study are part of the Diskos database and are publicly available via the Norwegian Petroleum Directorate. 


\section{Appendix A: Throw-length fault analyses}

Throw measurements were taken every $150 \mathrm{~m}$ along strike of key faults at various stratigraphic horizons to create a series of throw-length (T-x) plots. To accurately constrain the evolution of a fault, all fault slip-related strain must be explicitly recorded; this means that ductile deformation, such as faultparallel folding, and brittle strains associated with fault displacement must be incorporated into the throw-length plot (Duffy et al., 2015; Long and Imber, 2010; Meyer et al., 2002; Whipp et al., 2014). Where fault-parallel folding occurs, hangingwall and footwall cut-offs were defined by projecting the regional dip of the horizon, as measured some distance away from the fault, to the fault plane (see Fig. S1 in the Supplement). The discrepancy between projected (i.e. brittle plus ductile) and non-projected (i.e. brittle) throw measurements represents deformation accommodated via ductile means (e.g. folding; e.g. Duffy et al., 2015; Long and Imber, 2010). Footwall erosion occurs across some of the faults in the area, meaning the cut-offs of some stratigraphic horizons are absent (Fig. 1c). To constrain throw in these cases, and remove the effects of this erosion, we project the regional trend of the horizon, as measured from its sub-crop below the erosional unconformity updip, towards a projection of the fault plane (see Fig. S1).

\section{Appendix B: Fault displacement backstripping}

T-x plots were calculated across multiple stratigraphic horizons for each of the major faults. At each point along the fault, by systematically removing throw accrued during specific stratigraphic intervals, beginning with the youngest, we are able to determine the throw distribution along the fault at various points back in time. As such, we can also determine the lateral extent and any segmentation along the fault back in time; where backstripped throw is equal to zero, we can assume that the fault was not present in that location at the specified time. Due to independent constraints, obtained from isochron analysis, on the lateral extent of the fault at various points in its evolution, we use the "vertical throw subtraction" backstripping method (Chapman and Meneilly, 1991; Childs et al., 1993; Tvedt et al., 2016) as opposed to the modified "T-max method" (Dutton and Trudgill, 2009; Rowan et al., 1998; see discussion by Jackson et al., 2017). 


\section{The Supplement related to this article is available online at https://doi.org/10.5194/se-9-403-2018-supplement.}

Author contributions. The seismic interpretation and analyses throughout this study were undertaken by TP. Interpretations and evolutionary models were arrived at by TP, with additional input by CJ, RB and OD. The manuscript was written by TP, with additional input and scientific editing from CJ, RB and OD. All authors contributed to extensive discussions and ideas throughout the study and the writing of the manuscript.

Competing interests. The authors declare that they have no conflict of interest.

Acknowledgements. This contribution forms part of the MultiRift Project funded by the Research Council of Norway's PETROMAKS programme (project number 215591) and Statoil to the University of Bergen and partners Imperial College, University of Manchester and University of Oslo. The authors would like to thank PGS for providing and allowing us to show the seismic data used throughout this study. We would also like to thank Schlumberger for providing academic licences of the Petrel software to Imperial College. We are grateful for detailed reviews from Patricia Cadenas and an anonymous reviewer, along with a short comment from Alexander Peace, which improved the manuscript. In addition, we thank members of the Basins Research Group, in particular Alex Coleman and Matthew Reeve, for valuable discussions throughout this study.

Edited by: Gwenn Peron-Pinvidic

Reviewed by: Patricia Cadenas Martínez and one anonymous referee

\section{References}

Alasonati Tašárová, Z., Fullea, J., Bielik, M., and Środa, P.: Lithospheric structure of Central Europe: Puzzle pieces from Pannonian Basin to Trans-European Suture Zone resolved by geophysical-petrological modeling, Tectonics, 35, 722-753, 2016.

Autin, J., Bellahsen, N., Leroy, S., Husson, L., Beslier, M.-O., and d'Acremont, E.: The role of structural inheritance in oblique rifting: Insights from analogue models and application to the Gulf of Aden, Tectonophysics, 607, 51-64, 2013.

Babuška, V. and Plomerová, J.: The Sorgenfrei-Tornquist Zone as the mantle edge of Baltica lithosphere: new evidence from threedimensional seismic anisotropy, Terra Nova, 16, 243-249, 2004.

Bartholomew, I. D., Peters, J. M., and Powell, C. M.: Regional structural evolution of the North Sea: oblique slip and the reactivation of basement lineaments, Geological Society, London, Petroleum Geology Conference series 4, 1109-1122, 1993.
Bell, R. E., Jackson, C. A. L., Whipp, P. S., and Clements, B.: Strain migration during multiphase extension: Observations from the northern North Sea, Tectonics, 33, 1936-1963, 2014.

Bellahsen, N., Leroy, S., Autin, J., Razin, P., d'Acremont, E., Sloan, H., Pik, R., Ahmed, A., and Khanbari, K.: Pre-existing oblique transfer zones and transfer/transform relationships in continental margins: New insights from the southeastern Gulf of Aden, Socotra Island, Yemen, Tectonophysics, 607, 32-50, 2013.

Bergerat, F., Angelier, J., and Andreasson, P.-G.: Evolution of paleostress fields and brittle deformation of the Tornquist Zone in Scania (Sweden) during Permo-Mesozoic and Cenozoic times, Tectonophysics, 444, 93-110, 2007.

Berthelsen, A.: The Tornquist Zone northwest of the Carpathians: An intraplate pseudosuture, Gff, 120, 223-230, 1998.

Biddle, K. T. and Rudolph, K. W.: Early Tertiary structural inversion in the Stord Basin, Norwegian North Sea, J. Geol. Soc. London, 145, 603-611, 1988.

Bird, P. C., Cartwright, J. A., and Davies, T. L.: Basement reactivation in the development of rift basins: an example of reactivated Caledonide structures in the West Orkney Basin, J. Geol. Soc. London, 172, 77-85, 2014.

Bladon, A. J., Clarke, S. M., and Burley, S. D.: Complex rift geometries resulting from inheritance of pre-existing structures: Insights and regional implications from the Barmer Basin rift, J. Struct. Geol., 71, 136-154, 2015.

Brun, J.-P. and Tron, V.: Development of the North Viking Graben: inferences from laboratory modelling, Sediment. Geol., 86, 3151, 1993.

Brune, S., Corti, G., and Ranalli, G.: Controls of inherited lithospheric heterogeneity on rift linkage: Numerical and analogue models of interaction between the Kenyan and Ethiopian rifts across the Turkana depression, Tectonics, 36, 1767-1786, 2017.

Calignano, E., Sokoutis, D., Willingshofer, E., Brun, J. P., Gueydan, F., and Cloetingh, S.: Oblique Contractional Reactivation of Inherited Heterogeneities: Cause For Arcuate Orogens, Tectonics, 36, 542-558, 2017.

Cartwright, J. A.: The kinematics of inversion in the Danish Central Graben, Geological Society, London, Special Publications 44, 153-175, 1989.

Chamberlain, C. J., Houlié, N., Bentham, H. L. M., and Stern, T. A.: Lithosphere-asthenosphere interactions near the San Andreas fault, Earth Planet. Sc. Lett., 399, 14-20, 2014.

Chapman, T. J. and Meneilly, A. W.: The displacement patterns associated with a reverse-reactivated, normal growth fault, Geological Society, London, Special Publications 56, 183-191, 1991.

Cheng, X., Zhang, Q., Yu, X., Du, W., Liu, R., Bian, Q., Wang, Z., Zhang, T., and Guo, Z.: Strike-slip fault network of the Huangshi structure, SW Qaidam Basin: Insights from surface fractures and seismic data, J. Struct. Geol., 94, 1-12, 2017.

Childs, C., Easton, S. J., Vendeville, B. C., Jackson, M. P. A., Lin, S. T., Walsh, J. J., and Watterson, J.: Kinematic analysis of faults in a physical model of growth faulting above a viscous salt analogue, Tectonophysics, 228, 313-329, 1993.

Christensen, J. E. and Korstgård, J. A.: The Fjerritslev Fault offshore Denmark - salt and fault interactions, First Break 12, 1994.

Corti, G.: Continental rift evolution: From rift initiation to incipient break-up in the Main Ethiopian Rift, East Africa, Earth-Sci. Rev., 96, 1-53, 2009. 
Corti, G. and Dooley, T. P.: Lithospheric-scale centrifuge models of pull-apart basins, Tectonophysics, 664, 154-163, 2015.

Cotte, N. and Pedersen, H. A.: Sharp contrast in lithospheric structure across the Sorgenfrei-Tornquist Zone as inferred by Rayleigh wave analysis of TOR1 project data, Tectonophysics, 360, 75-88, 2002.

Coward, M. P., Dewey, J. F., Hempton, M., and Holroyd, J.: Tectonic evolution, in: The Millenium Atlas: petroleum geology of the central and northern North Sea, edited by: Evans, D., Graham, C., Armour, A., and Bathurst, P., Geological Society of London, 2003.

Daly, M. C., Chorowicz, J., and Fairhead, J. D.: Rift basin evolution in Africa: the influence of reactivated steep basement shear zones, Geol. Soc. London, Special Publication 44, 309-334, 1989.

Daly, M. C., Andrade, V., Barousse, C. A., Costa, R., McDowell, K., Piggott, N., and Poole, A. J.: Brasiliano crustal structure and the tectonic setting of the Parnaíba basin of NE Brazil: Results of a deep seismic reflection profile, Tectonics, 33, 2102-2120, 2014.

Deeks, N. R. and Thomas, S. A.: Basin inversion in a strike-slip regime: the Tornquist Zone, Southern Baltic Sea, Geological Society, London, Special Publications 88, 319-338, 1995.

de Paola, N., Holdsworth, R. E., and McCaffrey, K. J. W.: The influence of lithology and pre-existing structures on reservoir-scale faulting patterns in transtensional rift zones, J. Geol. Soc. London, 162, 471-480, https://doi.org/10.1144/0016-764904-043, 2005.

Destro, N.: Release fault: A variety of cross fault in linked extensional fault systems, in the Sergipe-Alagoas Basin, NE Brazil, J. Struct. Geol., 17, 615-629, 1995.

Dooley, T. P. and Schreurs, G.: Analogue modelling of intraplate strike-slip tectonics: A review and new experimental results, Tectonophysics, 574-575, 1-71, 2012.

Doré, A. G., Lundin, E. R., Fichler, C., and Olesen, O.: Patterns of basement structure and reactivation along the NE Atlantic margin, J. Geol. Soc. London, 154, 85-92, 1997.

Duffy, O. B., Bell, R. E., Jackson, C. A. L., Gawthorpe, R. L., and Whipp, P. S.: Fault growth and interactions in a multiphase rift fault network: Horda Platform, Norwegian North Sea, J. Struct. Geol., 80, 99-119, 2015.

Dutton, D. M. and Trudgill, B. D.: Four-dimensional analysis of the Sembo relay system, offshore Angola: Implications for fault growth in salt-detached settings, AAPG Bull., 93, 763-794, 2009.

Erlström, M., Thomas, S. A., Deeks, N., and Sivhed, U.: Structure and tectonic evolution of the Tornquist Zone and adjacent sedimentary basins in Scania and the southern Baltic Sea area, Tectonophysics, 271, 191-215, 1997.

Færseth, R. B.: Interaction of Permo-Triassic and Jurassic extensional fault-blocks during the development of the northern North Sea, J. Geol. Soc. London, 153, 931-944, 1996.

Fanavoll, S. and Lippard, S. J.: Possible Oblique-Slip Faulting in the Skagerrak-Graben, as Interpreted from High-Resolution Seismic Data. Norsk Geologisk Tidsskrift 74, 146-151, 1994.

Fazlikhani, H., Fossen, H., Gawthorpe, R., Faleide, J. I., and Bell, R. E.: Basement structure and its influence on the structural configuration of the northern North Sea rift, Tectonics, 36, 1151-1177, 2017.
Giba, M., Walsh, J. J., and Nicol, A.: Segmentation and growth of an obliquely reactivated normal fault, J. Struct. Geol., 39, 253-267, 2012.

Glennie, K. W.: Recent advances in understanding the southern North Sea Basin: a summary, Geological Society, London, Special Publications, 123, 17-29, 1997.

Gontijo-Pascutti, A., Bezerra, F. H. R., Terra, E. L., and Almeida, J. C. H.: Brittle reactivation of mylonitic fabric and the origin of the Cenozoic Rio Santana Graben, southeastern Brazil, J. S. Am. Earth Sci., 29, 522-536, 2010.

Grad, M., Janik, T., Yliniemi, J., Guterch, A., Luosto, U., Tiira, T., Komminaho, K., Środa, P., Höing, K., Makris, J., and Lund, C. E.: Crustal structure of the Mid-Polish Trough beneath the Teisseyre-Tornquist Zone seismic profile, Tectonophysics, 314, 145-160, 1999.

Grant, J. V. and Kattenhorn, S. A.: Evolution of vertical faults at an extensional plate boundary, southwest Iceland, J. Struct. Geol., 26, 537-557, 2004.

Graversen, O.: Structural analysis of superposed fault systems of the Bornholm horst block, Tornquist Zone, Denmark, Bulletin of the Geological Society of Denmark, 57, 25-49, 2009.

Guterch, A. and Grad, M.: Lithospheric structure of the TESZ in Poland based on modern seismic experiments, Geol. Q., 50, 2332, 2006.

Guterch, A., Grad, M., Materzok, R., and Perchuć, E.: The European Geotraverse Part 2 Deep structure of the Earth's crust in the contact zone of the Palaeozoic and Precambrian Platforms in Poland (Tornquist-Teisseyre zone), Tectonophysics, 128, 251279, 1986.

Hamar, G., Fjaeran, T., and Hesjedal, A.: Jurassic stratigraphy and tectonics of the south-southeastern Norwegian offshore, Petroleum Geology of the Southeastern North Sea and the Adjacent Onshore Areas, Springer, 103-114, 1983.

Hansen, D. L., Nielsen, S. B., and Lykke-Andersen, H.: The postTriassic evolution of the Sorgenfrei-Tornquist Zone - results from thermo-mechanical modelling, Tectonophysics, 328, 245267, 2000.

Heeremans, M. and Faleide, J. I.: Late Carboniferous-Permian tectonics and magmatic activity in the Skagerrak, Kattegat and the North Sea, Geological Society, London, Special Publications 223, 157-176, 2004.

Heeremans, M., Faleide, J. I., and Larsen, B. T.: Late Carboniferous -Permian of NW Europe: an introduction to a new regional map, Geol. Soc. London, Special Publication 223, 75-88, 2004.

Holdsworth, R., Stewart, M., Imber, J., and Strachan, R.: The structure and rheological evolution of reactivated continental fault zones: a review and case study. Geological Society, London, Special Publications 184, 115-137, 2001.

Hossein Shomali, Z., Roberts, R. G., and Pedersen, L. B.: Lithospheric structure of the Tornquist Zone resolved by nonlinear $\mathrm{P}$ and $\mathrm{S}$ teleseismic tomography along the TOR array, Tectonophysics, 416, 133-149, 2006.

Jackson, C. A. L. and Rotevatn, A.: 3-D seismic analysis of the structure and evolution of a salt-influenced normal fault zone: A test of competing fault growth models, J. Struct. Geol., 54, 215234, 2013.

Jackson, C. A. L., Chua, S. T., Bell, R. E., and Magee, C.: Structural style and early stage growth of inversion structures: 3 -D seismic 
insights from the Egersund Basin, offshore Norway, J. Struct. Geol., 46, 167-185, 2013.

Jackson, C. A.-L., Bell, R. E., Rotevatn, A., and Tvedt, A. B. M.: Techniques to determine the kinematics of synsedimentary normal faults and implications for fault growth models, Geological Society, London, Special Publications, 439, 2017.

Japsen, P., Bidstrup, T., and Lidmar-Bergström, K.: Neogene uplift and erosion of southern Scandinavia induced by the rise of the South Swedish Dome. Geological Society, London, Special Publications 196, 183-207, 2002.

Jensen, L. N. and Schmidt, B. J.: Neogene Uplift and Erosion Offshore South Norway: Magnitude and Consequences for Hydrocarbon Exploration in the Farsund Basin, in: Generation, Accumulation and Production of the Europe's Hydrocarbons III, edited by: Spencer, A. M., Springer, Special Publication of the European assocaiation fo Petroleum Geoscientists, 1993.

Jones, G., Rorison, P., Frost, R., Knipe, R., and Colleran, J.: Tectono-stratigraphic development of the southern part of UKCS Quadrant 15 (eastern Witch Ground Graben): implications for the Mesozoic-Tertiary evolution of the Central North Sea Basin, Geological Society, London, Petroleum Geology Conference series 5, 133-151, 1999.

Kinck, J. J., Husebye, E. S., and Larsson, F. R.: The Moho depth distribution in Fennoscandia and the regional tectonic evolution from Archean to Permian times, Precambrian Res., 64, 23-51, 1993.

Kind, R., Gregersen, S., Hanka, W., and Bock, G.: Seismological evidence for a very sharp Sorgenfrei-Tornquist Zone in southern Sweden, Geol. Mag., 134, 591-595, 1997.

Kirkpatrick, J. D., Bezerra, F. H. R., Shipton, Z. K., Do Nascimento, A. F., Pytharouli, S. I., Lunn, R. J., and Soden, A. M.: Scaledependent influence of pre-existing basement shear zones on rift faulting: a case study from NE Brazil, J. Geol. Soc. London, 170, 237-247, 2013.

Klemperer, S. and Hobbs, R.: The BIRPS Atlas: Deep seismic reflection profiles around the British Isles, Cambridge University Press, 1991.

Lăpădat, A., Imber, J., Yielding, G., Iacopini, D., McCaffrey, K. J. W., Long, J. J., and Jones, R. R.: Occurrence and development of folding related to normal faulting within a mechanically heterogeneous sedimentary sequence: a case study from Inner Moray Firth, UK, Geological Society, London, Special Publications 439, 2016.

Lassen, A. and Thybo, H.: Neoproterozoic and Palaeozoic evolution of SW Scandinavia based on integrated seismic interpretation, Precambrian Res., 204-205, 75-104, 2012.

Le Breton, E., Cobbold, P. R., and Zanella, A.: Cenozoic reactivation of the Great Glen Fault, Scotland: additional evidence and possible causes, J. Geol. Soc. London, 170, 403-415, 2013.

Lewis, M. M., Jackson, C. A. L., and Gawthorpe, R. L.: Saltinfluenced normal fault growth and forced folding: The Stavanger Fault System, North Sea, J. Struct. Geol., 54, 156-173, 2013.

Liboriussen, J., Ashton, P., and Tygesen, T.: The tectonic evolution of the Fennoscandian Border Zone in Denmark, Tectonophysics, 137, 21-29, 1987.

Lie, J. E. and Husebye, E. S.: Simple-shear deformation of the Skagerrak lithosphere during the formation of the Oslo Rift, Tectonophysics, 232, 133-141, 1994.
Long, J. J. and Imber, J.: Geometrically coherent continuous deformation in the volume surrounding a seismically imaged normal fault-array, J. Struct. Geol., 32, 222-234, 2010.

Mann, P.: Global catalogue, classification and tectonic origins of restraining- and releasing bends on active and ancient strike-slip fault systems, Geological Society, London, Special Publications 290, 13, 2007.

Mazur, S., Mikolajczak, M., Krzywiec, P., Malinowski, M., Buffenmyer, V., and Lewandowski, M.: Is the Teisseyre-Tornquist Zone an ancient plate boundary of Baltica?, Tectonics, 34, 2465-2477, 2015.

McBride, J. H.: Does the Great Glen fault really disrupt Moho and upper mantle structure?, Tectonics, 14, 422-434, 1995.

Meyer, V., Nicol, A., Childs, C., Walsh, J. J., and Watterson, J.: Progressive localisation of strain during the evolution of a normal fault population, J. Struct. Geol., 24, 1215-1231, 2002.

Michelsen, O. and Nielsen, L. H.: Structural development of the Fennoscandian Border Zone, offshore Denmark, Mar. Petrol. Geol., 10, 124-134, 1993.

Mogensen, T. E.: Palaeozoic structural development along the Tornquist Zone, Kattegat area, Denmark, Tectonophysics, 240, 191214, 1994.

Mogensen, T. E.: Triassic and Jurassic structural development along the Tornquist Zone, Denmark, Tectonophysics, 252, 197-220, 1995.

Mogensen, T. E. and Jensen, L. N.: Cretaceous subsidence and inversion along the Tornquist Zone from Kattegat to the Egersund Basin, First Break 12, 1994.

Mogensen, T. E. and Korstgård, J. A.: Triassic and Jurassic transtension along part of the Sorgenfrei-Tornquist Zone in the Danish Kattegat, Geological Survey of Denmark and Greenland Bulletin 1, 439-458, 2003.

Montalbano, S., Diot, H., and Bolle, O.: Asymmetrical magnetic fabrics in the Egersund doleritic dike swarm (SW Norway) reveal sinistral oblique rifting before the opening of the Iapetus, J. Struct. Geol., 85, 18-39, 2016.

Morley, C. K., Haranya, C., Phoosongsee, W., Pongwapee, S., Kornsawan, A., and Wonganan, N.: Activation of rift oblique and rift parallel pre-existing fabrics during extension and their effect on deformation style: examples from the rifts of Thailand, J. Struct. Geol., 26, 1803-1829, 2004.

Naylor, M. A., Mandl, G., and Supesteijn, C. H. K.: Fault geometries in basement-induced wrench faulting under different initial stress states, J. Struct. Geol., 8, 737-752, 1986.

Nielsen, L. H.: Late Triassic-Jurassic development of the Danish Basin and the Fennoscandian Border Zone, southern Scandinavia. The Jurassic of Denmark and Greenland, Geol. Surv. Den. Greenl., 1, 459-526, 2003.

Nixon, C. W., Sanderson, D. J., Dee, S. J., Bull, J. M., Humphreys, R. J., and Swanson, M. H.: Fault interactions and reactivation within a normal-fault network at Milne Point, Alaska, AAPG Bull., 98, 2081-2107, 2014.

Norling, E. and Bergström, J.: Mesozoic and Cenozoic tectonic evolution of Scania, southern Sweden, Tectonophysics, 137, 7-19, 1987.

Paul, D. and Mitra, S.: Fault patterns associated with extensional fault-propagation folding, Mar. Petrol. Geol., 67, 120-143, 2015. 
Peacock, D. C. P. and Sanderson, D. J. Displacements, segment linkage and relay ramps in normal fault zones, J. Struct. Geol., 13, 721-733, 1991.

Pegrum, R. M.: The extension of the Tornquist Zone in the Norwegian North Sea, Norsk Geol. Tidsskr., 64, 39-68, 1984.

Pharaoh, T. C.: Palaeozoic terranes and their lithopsheric boundaries within the Trans-European Suture Zone (TESZ): a review, Tectonophysics, 314, 17-41, 1999.

Phillips, T. B., Jackson, C. A. L., Bell, R. E., Duffy, O. B., and Fossen, H.: Reactivation of intrabasement structures during rifting: A case study from offshore southern Norway, J. Struct. Geol., 91, 54-73, 2016.

Rattey, R. P. and Hayward, A. B.: Sequence stratigraphy of a failed rift system: the Middle Jurassic to Early Cretaceous basin evolution of the Central and Northern North Sea, Geological Society, London, Petroleum Geology Conference, Series 4, 215-249, 1993.

Reeve, M. T., Bell, R. E., and Jackson, C. A. L.: Origin and significance of intra-basement seismic reflections offshore western Norway, J. Geol. Soc. London, 171, 1-4, 2013.

Richard, P.: Experiments on faulting in a two-layer cover sequence overlying a reactivated basement fault with oblique-slip, J. Struct. Geol., 13, 459-469, 1991.

Richard, P., Naylor, M., and Koopman, A.: Experimental models of strike-slip tectonics, Petrol. Geosci., 1, 71-80, 1995.

Ro, H. E., Stuevold, L. M., Faleide, J. I., and Myhre, A. M.: Skagerrak Graben - the Offshore Continuation of the Oslo Graben, Tectonophysics, 178, 1-10, 1990.

Rowan, M. G., Hart, B. S., Nelson, S., Flemings, P. B., and Trudgill, B. D.: Three-dimensional geometry and evolution of a saltrelated growth-fault array: Eugene Island 330 field, offshore Louisiana, Gulf of Mexico, Mar. Petrol. Geol., 15, 309-328, 1998.

Salomon, E., Koehn, D., and Passchier, C.: Brittle reactivation of ductile shear zones in NW Namibia in relation to South Atlantic rifting, Tectonics, 34, 70-85, 2015.

Scholz, C. H., Ando, R., and Shaw, B. E.: The mechanics of first order splay faulting: The strike-slip case, J. Struct. Geol., 32, 118126, 2010.

Schöpfer, M. P. J., Childs, C., Walsh, J. J., Manzocchi, T., and Koyi, H. A.: Geometrical analysis of the refraction and segmentation of normal faults in periodically layered sequences, J. Struct. Geol., 29, 318-335, 2007.

Schreurs, G.: Fault development and interaction in distributed strike-slip shear zones: an experimental approach, Geological Society, London, Special Publications 210, 35-52, 2003.

Sivhed, U.: A pre-Quaternary, post-Palaeozoic erosional channel deformed by strike-slip faulting, Scania, southern Sweden, Geol. Foren. Stock. For., 113, 139-143, 1991.

Skjerven, J., Rijs, F., and Kalheim, J.: Late Palaeozoic to Early Cenozoic structural development of the south-southeastern Norwegian North Sea, Petroleum Geology of the Southeastern North Sea and the Adjacent Onshore Areas, Springer, 35-45, 1983.

Sørensen, S. and Tangen, O. H.: Exploration trends in marginal basins from Skagerrak to Stord, in: Norwegian Petroleum Society Special Publications, edited by: Hanslien, S., Elsevier, 97114, 1995.
Stewart, S.: Displacement distributions on extensional faults: Implications for fault stretch, linkage, and seal, AAPG Bull., 85, 587-600, 2001.

Swanson, M. T.: Late Paleozoic strike-slip faults and related vein arrays of Cape Elizabeth, Maine, J. Struct. Geol., 28, 456-473, 2006.

Thybo, H.: Crustal structure and tectonic evolution of the Tornquist Fan region as revealed by geophysical methods, B. Geol. Soc. Denmark, 46, 145-160, 2000.

Thybo, H.: Crustal structure along the EGT profile across the Tornquist Fan interpreted from seismic, gravity and magnetic data, Tectonophysics, 334, 155-190, 2001.

Tommasi, A. and Vauchez, A.: Continental rifting parallel to ancient collisional belts: an effect of the mechanical anisotropy of the lithospheric mantle, Earth Planet. Sc. Lett., 185, 199-210, 2001.

Tvedt, A. B., Rotevatn, A., and Jackson, C. A.: Supra-salt normal fault growth during the rise and fall of a diapir: Perspectives from 3-D seismic reflection data, Norwegian North Sea, J. Struct. Geol., 91, 1-26, 2016.

Underhill, J. R. and Brodie, J. A.: Structural geology of Easter Ross, Scotland: implications for movement on the Great Glen fault zone, J. Geol. Soc. London, 150, 515-527, 1993.

Underhill, J. R. and Partington, M. A.: Jurassic thermal doming and deflation in the North Sea: implications of the sequence stratigraphic evidence, in: Petroleum Geology of Northwest Europe: Proceedings of the 4th Conference, 4, 337-345, Petroleum Geology Conference Proceedings, https://doi.org/10.1144/0040337, 1993.

Vauchez, A. and Tommasi, A.: Wrench faults down to the asthenosphere: Geological and geophysical evidence and thermomechanical effects, Geological Society, London, Special Publications 210, 15-34, 2003.

Vejbæk, O. V.: The Horn Graben, and its relationship to the Oslo Graben and the Danish Basin, Tectonophysics, 178, 29-49, 1990.

Vissers, R. L. M., van Hinsbergen, D. J. J., Meijer, P. T., and Piccardo, G. B.: Kinematics of Jurassic ultra-slow spreading in the Piemonte Ligurian ocean, Earth Planet. Sc. Lett., 380, 138-150, 2013.

Voss, P., Mosegaard, K., and Gregersen, S.: The Tornquist Zone, a north east inclining lithospheric transition at the south western margin of the Baltic Shield: Revealed through a nonlinear teleseismic tomographic inversion, Tectonophysics, 416, 151-166, 2006.

Walsh, J. J., Bailey, W. R., Childs, C., Nicol, A., and Bonson, C. G.: Formation of segmented normal faults: a 3-D perspective, J. Struct. Geol., 25, 1251-1262, 2003.

Whipp, P. S., Jackson, C. A. L., Gawthorpe, R. L., Dreyer, T., and Quinn, D.: Normal fault array evolution above a reactivated rift fabric; a subsurface example from the northern Horda Platform, Norwegian North Sea, Basin Res., 26, 523-549, 2014.

Withjack, M. O., Henza, A. A., and Schlische, R. W.: Threedimensional fault geometries and interactions within experimental models of multiphase extension, AAPG Bull., 101, 17671789, https://doi.org/10.1306/02071716090, 2017.

Wu, J. E., McClay, K., Whitehouse, P., and Dooley, T.: 4D analogue modelling of transtensional pull-apart basins, Mar. Petrol. Geol., 26, 1608-1623, 2009. 
Wylegalla, K., Bock, G., Gossler, J., and Hanka, W.: Anisotropy across the Sorgenfrei-Tornquist Zone from shear wave splitting, Tectonophysics, 314, 335-350, 1999.

Yielding, G.: The geometry of branch lines. Geological Society, London, Special Publications, 439, 2016.

Ziegler, P. A.: Collision related intra-plate compression deformations in Western and Central Europe, J. Geodynam., 11, 357-388, 1990.
Ziegler, P. A.: North Sea Rift System, Tectonophysics, 208, 55-75, 1992.

Ziegler, P. A. and Stampfli, G. M.: Late Palaeozoic-Early Mesozoic plate boundary reorganization: collapse of the Variscan orogen and opening of Neotethys, Natura Bresciana, 25, 17-34, 2001. 